\title{
Review \\ Fibre-Reinforced Polymer Reinforced Concrete Members under Elevated Temperatures: A Review on Structural Performance
}

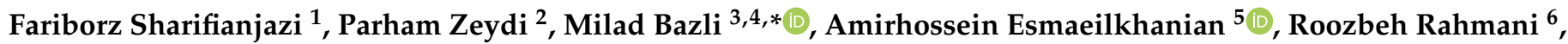 \\ Leila Bazli ${ }^{7}$ and Samad Khaksar ${ }^{1}$ \\ 1 School of Science and Technology, The University of Georgia, Tbilisi 0159, Georgia; \\ f.sharifianjazi@ug.edu.ge (F.S.); s.khaksar@ug.edu.ge (S.K.) \\ 2 Department of Technical and Engineering, Parsian Institute of Higher Education, Qazvin 3471991984, Iran; \\ parhamzeydi@gmail.com \\ 3 College of Engineering, IT \& Environment, Charles Darwin University, Darwin 0801, Australia \\ 4 School of Mechanical and Mining Engineering, The University of Queensland, Brisbane 4000, Australia \\ 5 Department of Materials and Metallurgical Engineering, Amirkabir University of Technology, \\ Tehran 1411713136, Iran; esmaeilkhanian-a@aut.ac.ir \\ 6 Faculty of Civil Engineering, University of Tabriz, Tabriz 5166614711, Iran; roozbeh.rahmani2000@gmail.com \\ 7 School of Metallurgy and Materials Engineering, Iran University of Science and Technology, \\ Tehran 1411713136, Iran; leilabazli64@gmail.com \\ * Correspondence: Milad.bazli@cdu.edu.au or m.bazli@uq.edu.au
}

check for updates

Citation: Sharifianjazi, F.; Zeydi, P.; Bazli, M.; Esmaeilkhanian, A.; Rahmani, R.; Bazli, L.; Khaksar, S. Fibre-Reinforced Polymer Reinforced Concrete Members under Elevated Temperatures: A Review on Structural Performance. Polymers 2022, 14, 472. https://doi.org/ $10.3390 /$ polym 14030472

Academic Editor: Henri Vahabi

Received: 29 December 2021

Accepted: 21 January 2022

Published: 25 January 2022

Publisher's Note: MDPI stays neutral with regard to jurisdictional claims in published maps and institutional affiliations.

Copyright: (C) 2022 by the authors. Licensee MDPI, Basel, Switzerland. This article is an open access article distributed under the terms and conditions of the Creative Commons Attribution (CC BY) license (https:// creativecommons.org/licenses/by/ $4.0 /)$.

\begin{abstract}
Several experimental and numerical studies have been conducted to address the structural performance of FRP-reinforced/strengthened concrete structures under and after exposure to elevated temperatures. The present paper reviews over 100 research studies focused on the structural responses of different FRP-reinforced/strengthened concrete structures after exposure to elevated temperatures, ranging from ambient temperatures to flame. Different structural systems were considered, including FRP laminate bonded to concrete, FRP-reinforced concrete, FRP-wrapped concrete, and concrete-filled FRP tubes. According to the reported data, it is generally accepted that, in the case of insignificant resin in the post curing process, as the temperature increases, the ultimate strength, bond strength, and structure stiffness reduce, especially when the glass transition temperature $T_{g}$ of the resin is approached and exceeded. However, in the case of post curing, resin appears to preserve its mechanical properties at high temperatures, which results in the appropriate structural performance of FRP-reinforced/strengthened members at high temperatures that are below the resin decomposition temperature $T_{d}$. Given the research gaps, recommendations for future studies have been presented. The discussions, findings, and comparisons presented in this review paper will help designers and researchers to better understand the performance of concrete structures that are reinforced/strengthened with FRPs under elevated temperatures and consider appropriate approaches when designing such structures.
\end{abstract}

Keywords: fibre-reinforced polymer; FRP strengthening; FRP-reinforced concrete; elevated temperature; fire

\section{Introduction}

Fibre-reinforced polymer is a composite material that consists of a polymer matrix and fibre reinforcement. Numerous FRPs have been produced, including basalt fibre-reinforced polymers (BFRP), glass fibre-reinforced polymers (GFRP), aramid fibre-reinforced polymers (AFRP), and carbon fibre-reinforced polymers (CFRP) [1-4]. FRPs have exceptional properties, including light weight, high strength, electrical insulation, low thermal conductivity, impact resistance, dimensional stability, corrosion resistance, and they are nonmagnetic [5-8]. Due to the significant advantages of FRPs over conventional construction materials, including steel and concrete, for retrofitting and strengthening concrete structures, they have gained attention as viable alternatives for reinforcing and retrofitting 
concrete structures [8-10]. These composites are typically employed as "externally bonded" systems to increase the axial sectional, flexural, torsion, and shear capacities of the structural elements of the reinforced concrete, increase the structural members' stability and serviceability, and provide additional confinement [11-13]. Two distinct types of strengthening methods for FRP-reinforced concrete (FRP-RC) are presented: the first makes use of FRP sheets and/or plates and the second uses near-surface mounted (NSM) bars [14]. To prepare the external surface of the concrete for FRP plates and sheets, either high-pressure jet washing or sandblasting is used. Following that, FRP products are used on the concrete surface [15-18]. This form of external reinforcement is simple and quick to implement. Three types of FRP reinforcements are available for new structures: (1) internal reinforcement with FRP bars; (2) FRP formwork for RC members that stays in place; and (3) FRP tendons for prestressed concrete (PC) components [19-21].

Due to concerns about the performance of FRPs at high temperatures, the widespread application of FRP-RC in structures has been limited [22-24]. In general, prolonged contact with temperatures around and above the glass transition temperature $\left(T_{g}\right)$ of the resin degrades the mechanical properties of FRP materials [25]. $T_{g}$ is normally represented by a single $T_{g}$ (often between 50 and $120^{\circ} \mathrm{C}$ for resins cured at ambient temperatures), which can be evaluated experimentally using differential scanning calorimetry (DSC) or determined by dynamic mechanical analyses (DMA) $[17,26]$. In design decision-making, $T_{g}$ is frequently used as a "critical temperature", although mechanical performance degrades prior to reaching $T_{g}$ [27]. When subjected to elevated temperatures (usually greater than $300-400{ }^{\circ} \mathrm{C}$ ), the thermal decomposition of the FRP organic matrix occurs, potentially emitting smoke, soot, toxic/combustible volatiles, and heat [7,28-30]. Organic fibres (e.g., biofibres, $\mathrm{PBO}$, and aramid) employed to strengthen some polymer composites may also degrade and form smoke, fumes, and heat [31,32]. These decomposition processes often result in the further deterioration of the physical and mechanical properties of FRPs due to the degradation of the matrix and, in certain circumstances, the fibres [6,33,34]. Deuring [35] is one of the leading researchers conducting fire tests on externally reinforced concrete beams. According to Deuring's report, unprotected beams that were strengthened with FRP could withstand a fire for $81 \mathrm{~min}$. In comparison, a similar beam with protected FRP systems could withstand a fire for $146 \mathrm{~min}$. Williams et al. [36] conducted a more recent investigation, in which they tested the performance of CFRP-strengthened RC Tbeams under normal fire conditions. The beams were insulated with vermiculite gypsum (VG) insulation. The findings of this experiment revealed that FRP and reinforcing steel components can be kept at a temperature below the critical value necessary to retain their structural integrity by using a suitably insulated system.

The purpose of this review is to summarise and discuss the findings of investigations on the performance and mechanical properties of FRP-reinforced/strengthened concrete members under elevated temperatures.

\section{Mechanical Properties of Individual Components at Elevated Temperature}

\subsection{FRP}

FRPs exhibit significantly different behaviours from steel or concrete at high temperatures. When exposed to a substantial amount of heat, all polymer matrix composites will burn. Additionally, matrix elements, such as epoxy, vinylester, and polyester, not only facilitate burning but also produce huge amounts of dense black smoke [37]. Furthermore, FRPs degrade in terms of stiffness, strength, and bond characteristics when exposed to even mildly elevated temperatures [38,39]. Numerous research investigations focusing on the mechanical characteristics of FRPs and their constituents at elevated temperatures have been published in the literature [40-44].

When elevated temperatures below $T_{g}$ are applied to the resin matrix, the resin matrix remains relatively unaffected (i.e., some microcracks may form) and the surface of the resin matrix remains rough and similar to that of the unconditioned sample [45]. In this situation, no significant changes occur in the strength or stiffness of the FRP composites. 
When FRP composites reach their $T_{g}$, the resin undergoes a phase transition from glassy to rubbery. In this instance, the FRP materials soften and creep, resulting in a significant loss of stiffness and strength [46]. It has been observed that when FRP materials are subjected to temperatures that are near the resin's decomposition temperature, their organic matrix decomposes, which emits heat, soot, smoke, and hazardous volatiles. Exposure to such high temperatures (e.g., $300-500{ }^{\circ} \mathrm{C}$ ) causes the breakage of the modular chains of the resin, chemical bonds, and bonds between the fibres [47,48]. At higher temperatures, the composites ignite and burn. The critical temperature (i.e., the temperature at which $50 \%$ of the strength is lost) was reported to be typically between $87-90^{\circ} \mathrm{C}$ for pultruded GFRP profiles in compression, $300-330^{\circ} \mathrm{C}$ for FRP reinforcing bars in tension, $180-250{ }^{\circ} \mathrm{C}$ for laminates in bending, and $200-300{ }^{\circ} \mathrm{C}$ for laminates in tension [49]. Figure 1 shows the reported critical temperatures in the literature (i.e., the temperatures that are equivalent to an approximately $50 \%$ reduction in mechanical properties) for different FRP composites under different loading conditions.
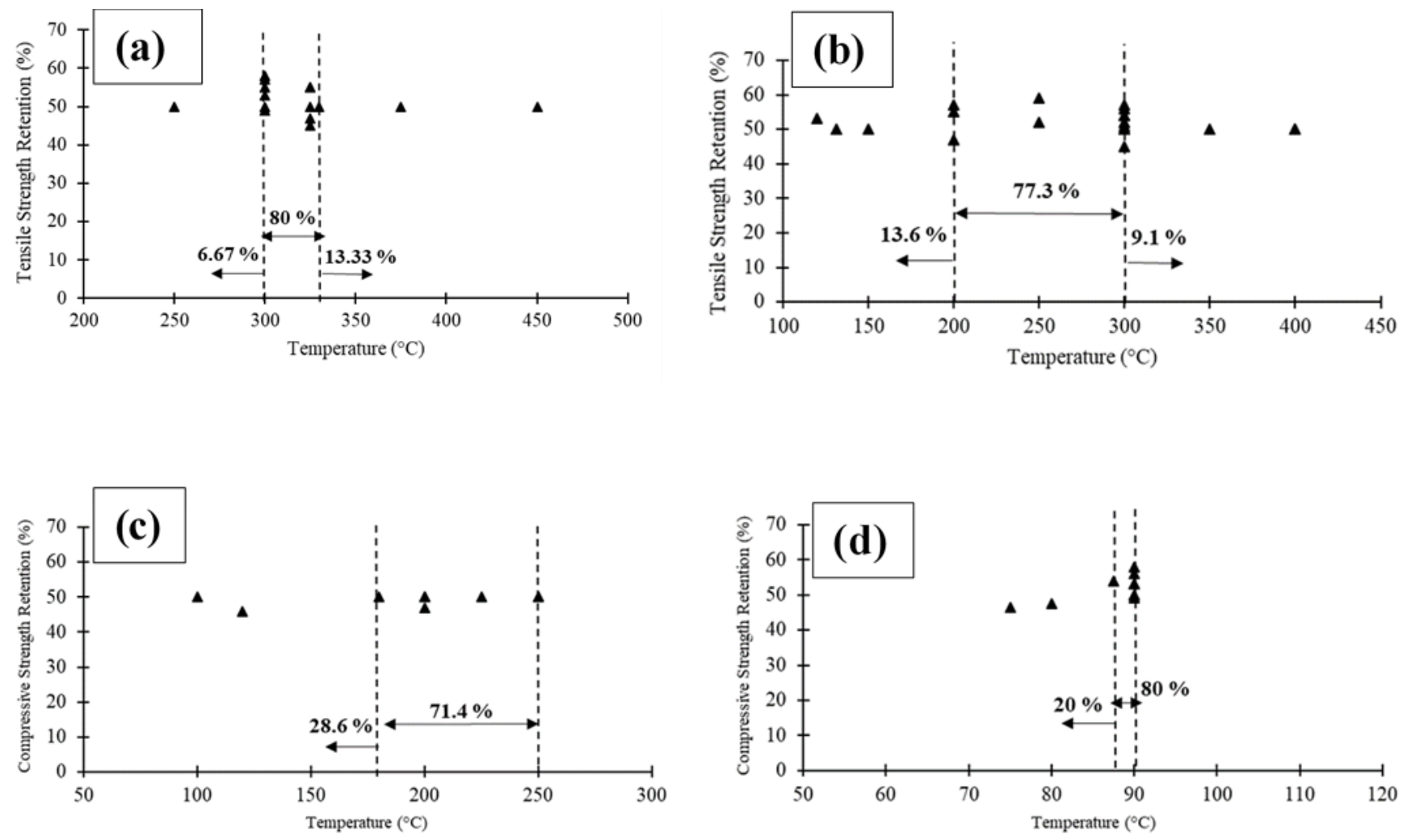

Figure 1. The FRP strength retention versus critical temperature as reported in the literature [50]: (a) FRP bars; (b) FRP laminates; (c) FRP laminates; and (d) pultruded FRP profiles.

The compression and interlaminar shear failure of FRP composites occurs at substantially lower loads and temperatures than flexure and tension [50]. Elevated temperatures have a lesser effect on the elastic modulus of FRP composites than on the corresponding strength values. This is mostly due to the fact that the elastic modulus of FRP composites is more closely related to the elastic modulus of the fibres than to the elastic modulus of the resin [49].

A few of the parameters that influence the properties of FRPs are the configuration of fibres and resin, the production technique, and the quality control of the final products. The stiffness and strength properties of FRPs decrease with increasing temperature, although there are considerable variations in the results due to the wide variety of fibre volume fractions, formulations of the matrix, and fibre orientations represented in the data [33,51]. 


\subsection{Concrete}

While concrete generally has a high resistance to fire, its mechanical characteristics, such as elastic modulus and strength, degrade when exposed to high temperatures. At elevated temperatures, the failure is mostly due to the creation of cracks that are parallel to the heated surface, changes in the chemistry, and an increase in pore pressure owing to water evaporation. At elevated temperatures, concrete undergoes a variety of physical (vapor diffusion, evaporation, phase expansion, and condensation), chemical (dehydration and thermo-chemical damage), and mechanical (cracking, spalling, and thermo-mechanical damage) phenomena that degrade its qualities $[52,53]$. The water on the surface of the concrete and capillary water evaporates as the temperature rises and this process is hastened by the reduced cohesive interactions between the water molecules, which is caused by water expansion. At $105{ }^{\circ} \mathrm{C}$, the free water begins to evaporate rapidly. The dehydration of ettringite occurs between 80 and $150^{\circ} \mathrm{C}$, followed by gypsum decomposition between 150 and $170{ }^{\circ} \mathrm{C}$. When the temperature approaches $300^{\circ} \mathrm{C}$, the evaporation of the chemically bound water begins, which reduces the compressive strength of concrete $[31,36,54-57]$. Portlandite decomposes between 400 and $540{ }^{\circ} \mathrm{C}$ as the temperature increases further. When the temperature of the concrete exceeds $400{ }^{\circ} \mathrm{C}$, the strength of the concrete deteriorates more rapidly due to the breakdown of calcium-silica-hydrate (C-S-H). Between 600 and $800{ }^{\circ} \mathrm{C}$, the second phase of the $\mathrm{C}-\mathrm{S}-\mathrm{H}$ decomposes to create $\beta$-dicalcium silicate $\left(\beta-\mathrm{C}_{2} \mathrm{~S}\right)$. At $900{ }^{\circ} \mathrm{C}$, the $\mathrm{C}-\mathrm{S}-\mathrm{H}$ fully degrades. As a result, the critical temperature range for concrete is around $400-900{ }^{\circ} \mathrm{C}$ and concrete loses the majority of its strength within this range [58].

\section{FRP-RC Structural Members}

FRPs and concrete could be used to construct different structural systems [59-61]. Figure 2 shows the common applications of using FRPs together with concrete elements. However, owing to the unique advantages of such hybrid structures, many other applications could be considered, especially in offshore infrastructures. In this section, the studies that focused on each of the systems shown in Figure 2 are reviewed and discussed in detail.

\subsection{FRP Laminate Bonded to Concrete}

The majority of options for fibre-reinforced strengthening by external bonding are based on polymer systems, most notably those of epoxies [62]. Typically, they serve as the matrix for FRP laminates; nevertheless, they are occasionally used as a primer for the substrate. Their relatively low $T_{g}$ is one disadvantage of epoxies, which may occur around $40-50{ }^{\circ} \mathrm{C}$ for the commercially available epoxy resins that are used in structural engineering. At that temperature, the epoxy polymer transforms from a stiff to a viscous (soft) state, reducing the adhesion between the reinforced element and the FRP laminate. As a result, the majority of EBR-FRP solutions are vulnerable to high temperatures. It is not usually clear whether the issue is limited to fire conditions or whether it may also occur as a result of sun exposure [63-66].

Thermal loading affects the bond behaviour of the interface of FRP and concrete in two ways, which influences the stress transmission between the FRP and the concrete as well as the load-bearing capacity of the FRP strengthening system. Property changes in the bonding adhesive and the two adhesives induced by the temperature are caused by the first effect, whereas the second effect is caused by the thermal incompatibility of FRP and concrete. The first effect is due to the low $T_{g}$ of bonding adhesives that are cured at the ambient temperature (commonly epoxy resins), which is normally between 45 and $80^{\circ} \mathrm{C}$. Upon service temperatures above the $T_{g}$ value, the adhesive changes from a solid to a viscous state, resulting in a loss of strength and stiffness. Such bonding adhesive property degradations impair the bond behaviour of the interface, resulting in the stress transfer loss between materials and the early debonding failure of the FRP laminate [66-68]. The second effect (thermal stress effect), on the other hand, is primarily associated with the fact that the concrete and the FRP laminate have different thermal expansion coefficients (CTEs). Due to the determination of the longitudinal CTE of the FRP laminate by the 
thermal expansion of the fibres, it is different from the longitudinal CTE of concrete. This value for the CFRP laminates that are extensively employed for reinforcing purposes, for example, is near to zero, whereas the CTE of concrete is approximately $10 \times 10^{-6} /{ }^{\circ} \mathrm{C}$ at ambient temperatures. Consequently, the aforementioned thermal incompatibility could cause large thermal stresses at the interface of these two materials, thereby affecting the load-bearing capacity of the strengthened structures [69].

FRP reinforcing bar
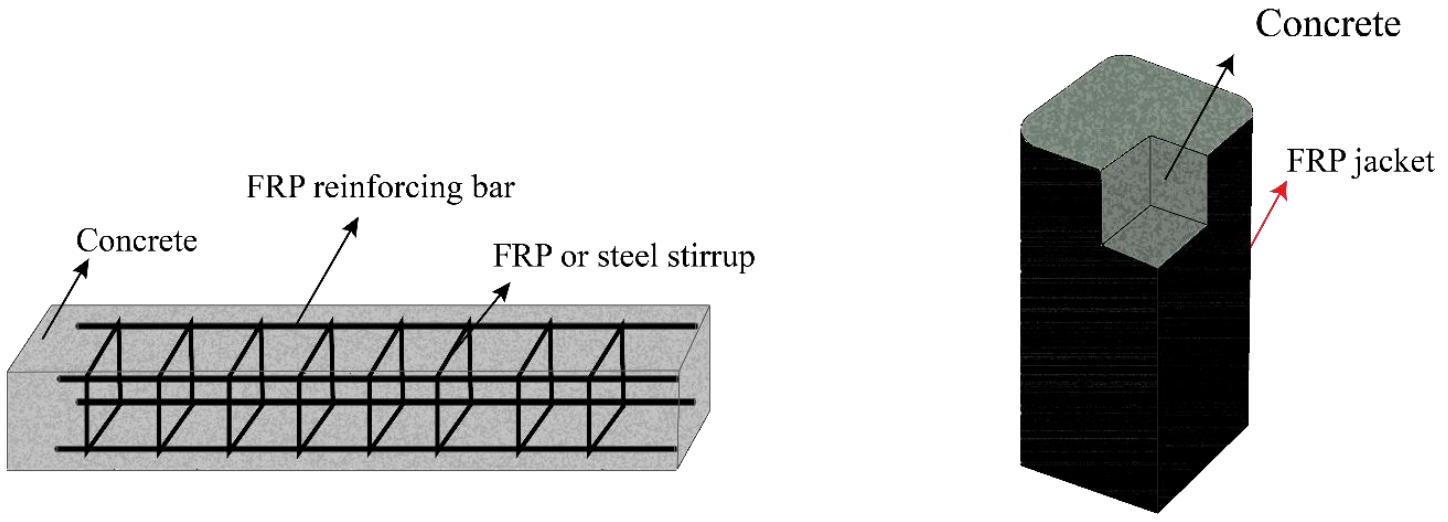

(a)

(b)

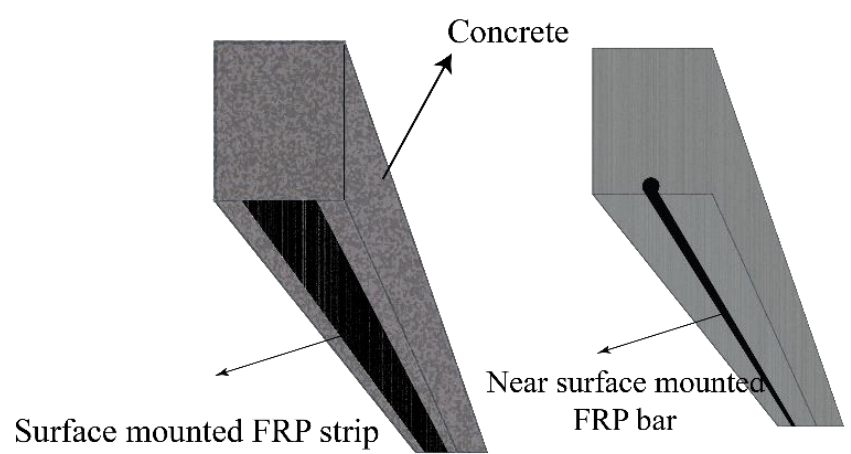

(c)

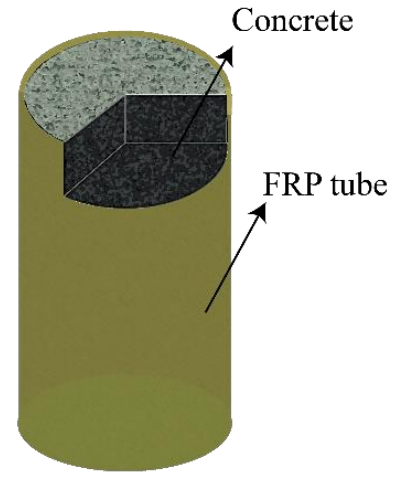

(d)

Figure 2. The common applications of concrete members that are reinforced/strengthened with FRP [14]: (a) an FRP-reinforced concrete member; (b) an FRP-wrapped concrete member; (c) an FRP-NSM strip/bar; (d) a concrete filled FRP tube. Reproduced from [14], with permission from Elsevier, 2022.

This issue is not limited to fire conditions; it can also develop after being warmed by the sun's rays. In a study by Krzywoń [70], concrete beams were strengthened with an externally bonded CFRP strip and the beams were then heated with linear infrared radiators on the strengthened side and loaded to failure using the bending test. Noticeable temperature effects appeared from about $50^{\circ} \mathrm{C}$. As the temperature increased from room temperature to $73^{\circ} \mathrm{C}$, the failure mode changed from concrete debonding to adhesive debonding; the failure moment also decreased from 72.5 to $55.4(\mathrm{kNm})$. Failure was followed by delamination in all cases. CFRP strip delamination happened suddenly and unexpectedly, with no obvious warning signs. The significant bearing capacity loss appeared at temperatures over $65^{\circ} \mathrm{C}$. It has been reported that, under service load conditions, the insulated beams and slabs that are strengthened with CFRP can endure four and three hours of standard fire exposure, respectively, thanks to the fire insulation [71].

Despite the vulnerability of epoxy resin to elevated temperatures, post curing of resin during exposure to elevated temperatures may cause some strength improvement [27]. It 
was reported that the post curing of CFRP-strengthened reinforced concrete beams can change its performance at elevated temperatures. The results demonstrated that when exposed to high temperatures, post curing an FRP system could be an efficient way to improve the performance of the beams that were strengthened with FRPs. The failure of the epoxy layer started at $120^{\circ} \mathrm{C}$ and $170{ }^{\circ} \mathrm{C}$ for the uncured and post cured FRP systems, respectively. In the sustained load/increasing temperature tests, the failure mode for uncured and post cured samples were different. The post curing of the FRPs appears to preserve the strength of epoxy at high temperatures. FRP debonding and rupture were the failure cause of the uncured members, while the failure of the post cured specimens was due to concrete delamination and no FRP rupture in higher-temperature testing was observed [72].

In order to numerically model FRP reinforced concrete structures, concrete is often simulated as a nonlieanr material using a model derived by Williams and Warnke [73]. In their models, nonlinerity is tacken into acount considering concrte cracking in tension, and crushing in compression, as well as any internal reinforcement plasticity development [74]. These nonlinear effects are often considered by a multi-nonlinear stress-strain curve. The model proposed by Hognestad et al. [75] is one of the most popular concrete stress-strain curve:

$$
\begin{gathered}
f_{c}=f_{c}^{\prime}\left[\frac{2 \varepsilon_{c}}{\varepsilon_{c o}}-\left(\frac{\varepsilon_{c}}{\varepsilon_{c o}}\right)^{2}\right] \quad 0 \leq \varepsilon_{c} \leq \varepsilon_{c o} \\
f_{c}=f_{c}^{\prime}-\left(\frac{0.15 f_{c}^{\prime}}{\varepsilon_{c}-\varepsilon_{c o}}\right) \quad \varepsilon_{c}>\varepsilon_{c o}
\end{gathered}
$$

where, $f_{c}^{\prime}$ is concrete compressive strength $(\mathrm{MPa}), f_{c}$ is concrete compressive stress $(\mathrm{MPa})$ corresponding to the strain value $\varepsilon_{c}$, and $\varepsilon_{c o}=\frac{2 f_{c}^{\prime}}{E_{c}}$.

In terms of modeling FRP composites, the material characteristics of FRPs are normally considered orthotropic and elastic until reaching to the ultimate strength, which it drops to zero [76]. The bond between FRP and concrete can also be modeled using commonly accepted bond-slip models with proposed by different researchers/standards, such as CEB-FIP model [77]:

$$
\tau=\tau_{u}\left(\frac{S}{S_{u}}\right)^{0.4}
$$

where, $\tau$ is the bond stress corresponding to the given slip $(S)$ in $(\mathrm{MPa}), \tau_{u}$ is the maximum bond stress in (MPa), $S$ is the relative slip corresponding to a given shear stress in $(\mathrm{mm})$, and $S_{u}$ is the ultimate slip corresponding to $\tau_{u}$ in $(\mathrm{mm})$.

Additionally, a suite of numerical fire simulation software is also being developed in the experimental program, [78,79]. Complex one- and two-dimensional finite difference heat transfer algorithms are combined with strain compatibility-equilibrium evaluations in the numerical models. Models have been created to estimate the load capacity variation and heat transfer behaviour of several types of insulated, uninsulated, FRP-strengthened, and un-strengthened reinforced concrete elements under exposure to pre-defined (standard) fire situations. The models can account for a wide range of variables in their analyses, including the sustained applied load magnitude, size and shape (T-beams or rectangular) of specimens, standard fire type, concrete moisture content, concrete aggregate type, steel reinforcement ratios, bar layouts, FRP type, thickness and width, as well as insulation type, configuration, and thickness. The studies can additionally account for insulation and/or FRP delamination at pre-determined times during a fire. The models are being tested against the findings of the fire tests with the goal of using them to anticipate fire endurance and perform parametric studies that could help engineers to develop fire-resistant FRP strengthening systems. Parallel to the experimental program, modelling efforts are also ongoing. Attempts are being made to better understand and simulate the thermal and mechanical properties of FRP materials at elevated temperatures, with a particular emphasis on the thermally induced degradation of the FRP-concrete bond. 
Along with standard numerical approaches, a homogenisation approach $[80,81]$ has been developed to overcome the challenges associated with conventional methods when analysing the thermal behaviour of multi-material component systems. It has been demonstrated that the findings acquired using the homogenisation approach agree well with those obtained using the micromechanics approach.

Hawileh et al. [82] established a three-dimensional finite element model of the CFRPreinforced T-section $\mathrm{RC}$ beams that were evaluated by Williams et al. [36]. The FE model, which was developed using a commercial finite element software, takes into consideration the changes in the mechanical and thermal properties of the constituent materials and conducts separate structural and thermal evaluations. The failure of the strengthening system due to delamination or the degradation of the adhesive was simulated using a simple element-killing procedure when the temperature in the CFRP exceeded $250{ }^{\circ} \mathrm{C}$ (for which a strength reduction of $50 \%$ was assumed) and the shear stress at the interface of CFRP and concrete exceeded 4.5 MPa. The model's predictions were consistent with experimental temperatures.

Kodur and Ahmed [83] and Ahmed and Kodur [55] both developed numerical procedures for simulating the mechanical and thermal responses of RC beams that were reinforced with CFRP strips when exposed to fire using the EBR technique. The procedures were carried out using a "macroscopic finite element model" that took into account arbitrary thermal insulation, temperature-dependent material properties, load and constraint conditions, loading schemes and fire scenarios, geometric and material nonlinearity, and appropriate failure criteria. Following a 2D heat transfer analysis of the cross-section, the model entailed the following steps: (i) the calculation of the slip strain at the interface of the CFRP and concrete; and (ii) the generation of moment vs. curvature curves for each time step and beam segment, followed by the computation of internal forces and deflections from beam analysis. Comparing the model to the experimental data that was reported by Blontrock et al. [84] and Ahmed and Kodur [85] validated the model. In general, good agreement was found in terms of the time, temperatures, and deflections required for the strengthening system to delaminate. Additionally, it was demonstrated that reaching $T_{g}$ in the CFRP does not necessarily result in the failure of CFRP-strengthened RC beams and that more realistic fire limit states should be developed. Several further computational models [86-88] for FRP-strengthened concrete members have been established and verified using experimental data.

Table 1 summarises the study plan and results that were reported by several researchers on the structural responses of concrete members that were strengthened with different types of FRP laminates. Different test set-ups were used to study both the ultimate load capacity and the bond strength between the FRP and concrete. Figure 3 schematically shows the different set-ups used by researchers. As seen in Table 1, regardless of the FRP type and laminate thickness, both the bonding strength and the ultimate load-carrying capacity of FRP-strengthened concrete members decrease significantly under moderate and high temperatures, and specifically when the exposure temperature reaches and exceeds the resin glass transition temperature. From Table 1, it can be concluded that the epoxy resin that is used to bond the FRP to concrete plays a key role in the performance of the FRP-bonded concrete systems. Therefore, using resins with appropriate thermo-mechanical characteristics (e.g., high resin glass transition temperature $T_{g}$ and decomposition temperature $T_{d}$ ) results in a better performance in moderate temperatures (i.e., higher strength retention) and under fire conditions (i.e., longer duration until failure). 
Table 1. The research plan and results summary of the reported structural responses of concrete members strengthened with FRP laminates.

\begin{tabular}{|c|c|c|c|c|c|c|c|}
\hline Ref & Study Type & Sample & FRP Type & $T_{g}\left({ }^{\circ} \mathrm{C}\right)$ of Resin & Exposure Condition & Test Type & Results \\
\hline [70] & Experimental & $\begin{array}{l}\text { Externally bonded } \\
\text { concrete beams }\end{array}$ & $\begin{array}{l}\text { A laminate of a single } \\
\text { layer CFRP sheet }\end{array}$ & NA & $20-80^{\circ} \mathrm{C}$ & Bending test & $\begin{array}{l}\text { Significant degradation occurred in } \\
\text { the bearing capacity above } 65^{\circ} \mathrm{C} \text {. } \\
\text { Failure moment decreased from } 72.5 \\
\text { to } 55.4 \mathrm{kNm} \text {. }\end{array}$ \\
\hline [71] & $\begin{array}{l}\text { Experimental and } \\
\text { numerical }\end{array}$ & $\begin{array}{l}\text { RC flexural members, } \\
\text { RC slabs }\end{array}$ & $\begin{array}{l}\text { One layer of CFRP + } \\
\text { isolation layer }\end{array}$ & NA & Fire & Bending test & $\begin{array}{l}\text { For four hours, RC beams reinforced } \\
\text { with CFRP and supplemented with } \\
\text { spray (thickness of } 19 \text { and } 32 \mathrm{~mm} \text { ) } \\
\text { could withstand service load levels. } \\
\text { Three hours could be withstood by } \\
\text { CFRP-reinforced RC slabs } \\
\text { accompanied with fire insulation } \\
\text { (thickness of } 19 \text { and } 25 \mathrm{~mm} \text { ). At } \\
\text { temperatures that were far higher } \\
\text { than the polymer's } T_{g} \text {, the complete } \\
\text { loss of the CFRP-concrete composite } \\
\text { action occurred. The numerical model } \\
\text { presented in this research can be used } \\
\text { to accurately assess the fire response } \\
\text { of the flexural components of } \\
\text { CFRP-strengthened concrete. }\end{array}$ \\
\hline [89] & Experimental & Concrete prisms & CFRP strips & NA & $\begin{array}{c}1 \text { and } 2 \mathrm{~h} \text { at } 200,400, \\
\text { and } 600^{\circ} \mathrm{C}\end{array}$ & Single-lap shear & $\begin{array}{l}\text { For thermal exposure of } 1 \mathrm{~h} \text { at } 200 \text {, } \\
400 \text {, and } 600{ }^{\circ} \mathrm{C} \text {, the residual bond } \\
\text { strength employing epoxy adhesive } \\
\text { was } 94,79 \text {, and } 49 \% \text {, respectively. For } \\
2 \text { h of exposure, the equivalent values } \\
\text { were } 86,75 \text {, and } 41 \% \text {, respectively. For } \\
\text { temperature exposures of } 1 \mathrm{~h} \text { at } 200, \\
400 \text {, and } 600^{\circ} \mathrm{C} \text {, the residual bond } \\
\text { strength following the repair of the } \\
\text { heat-damaged concrete with CFRP } \\
\text { using a cement-based adhesive was } \\
91,79 \text {, and } 70 \% \text {, respectively. }\end{array}$ \\
\hline
\end{tabular}


Table 1. Cont.

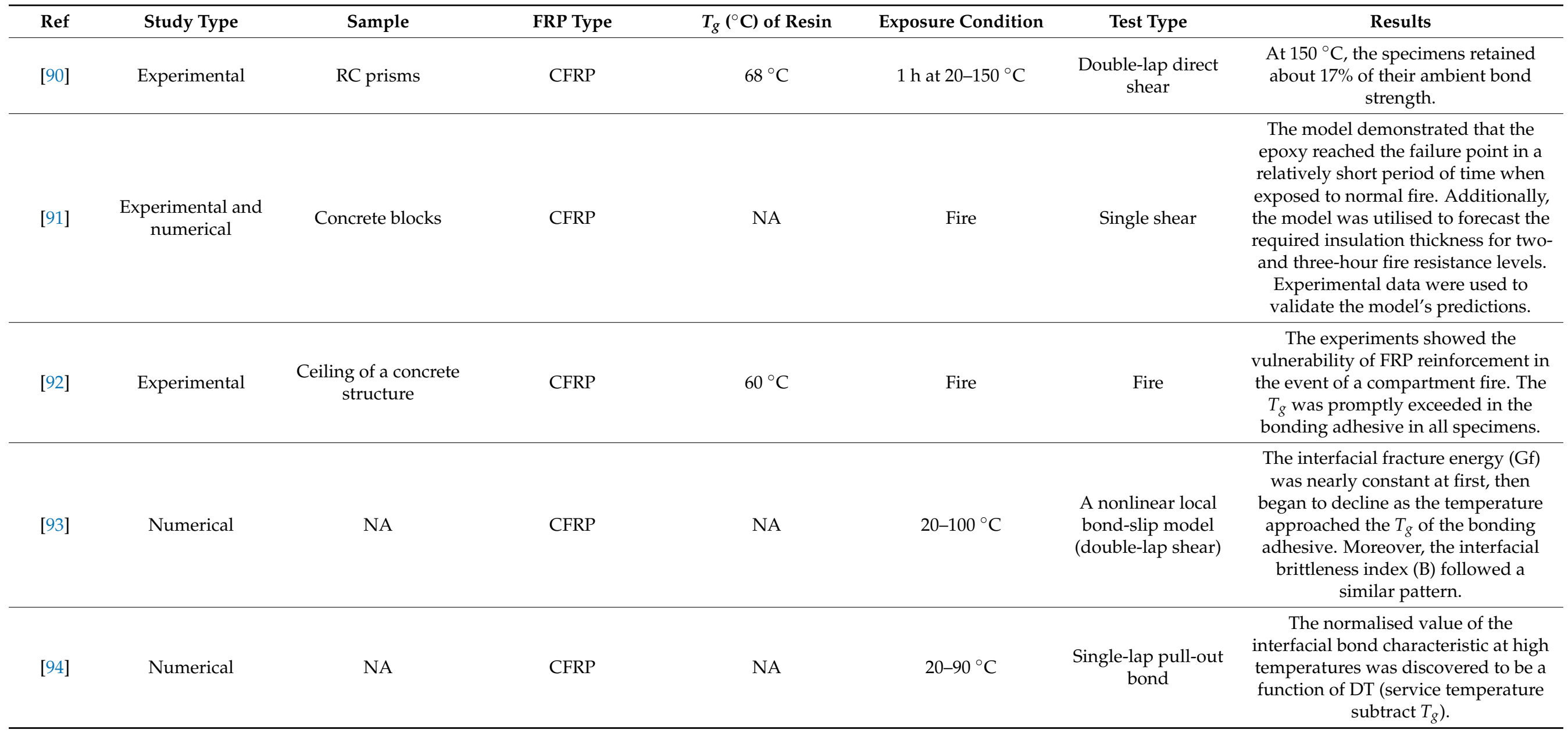


Table 1. Cont.

\begin{tabular}{|c|c|c|c|c|c|c|c|}
\hline Ref & Study Type & Sample & FRP Type & $T_{g}\left({ }^{\circ} \mathrm{C}\right)$ of Resin & Exposure Condition & Test Type & Results \\
\hline [56] & Experimental & $\begin{array}{l}\text { Rectangular concrete } \\
\text { specimens }\end{array}$ & $\begin{array}{c}\text { CFRP sheet and } \\
\text { laminate and GFRP } \\
\text { sheet }\end{array}$ & $55^{\circ} \mathrm{C}$ & $20-80^{\circ} \mathrm{C}$ & $\begin{array}{l}\text { Double-face pure } \\
\text { shear }\end{array}$ & $\begin{array}{l}\text { With service temperatures exceeding } \\
\text { the } T_{g} \text { of the adhesive, the maximum } \\
\text { bond stress was reduced. } \tau_{\text {max }} \text { was } \\
\text { reduced by } 25 \% \text { in the case of CFRP } \\
\text { laminate, } 72 \% \text { in the case of GFRP } \\
\text { sheet, and } 54 \% \text { in the case of CFRP } \\
\text { sheet at } 80^{\circ} \mathrm{C} \text { compared to room } \\
\text { temperature. }\end{array}$ \\
\hline
\end{tabular}




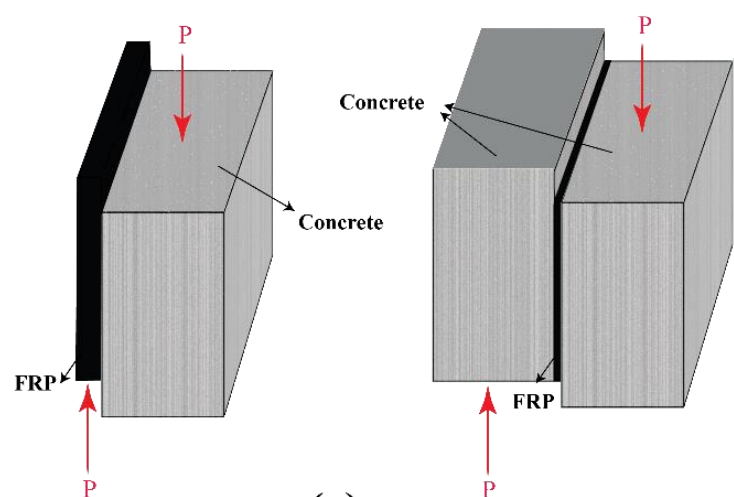

(a)

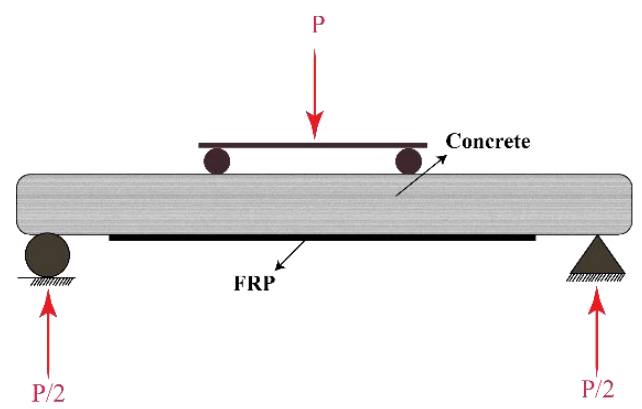

(c)

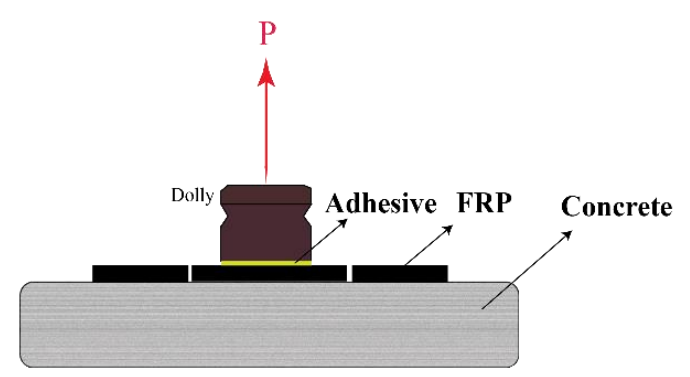

(e)

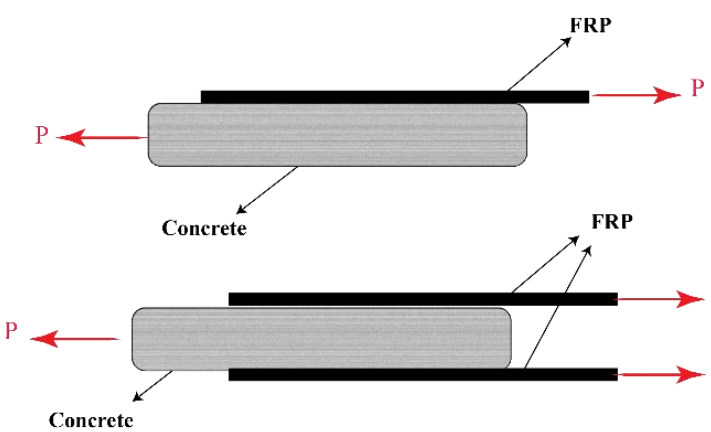

(b)

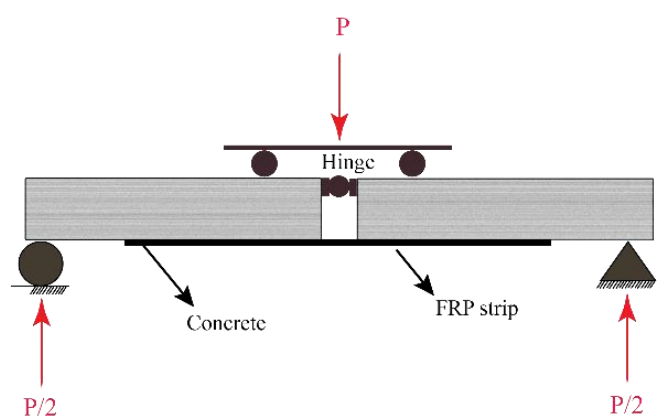

(d)

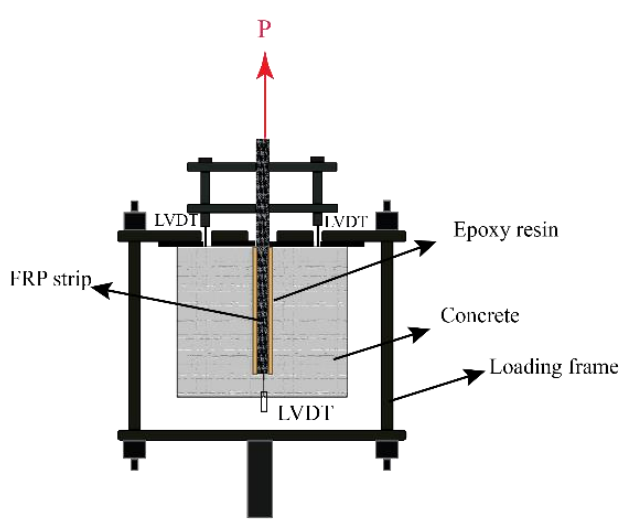

(f)

Figure 3. The set-ups that were used to test FRP strips/laminates bonded to concrete: (a) shear block; (b) lab shear; (c) ultimate strength four-point bend; (d) bond strength flexural test; (e) pull-off; and (f) direct pull-out. Reproduced from [14], with permission from Elsevier, 2022.

\subsection{Reinforced Concrete Members \\ 3.2.1. Bond Performance}

For transferring loads through the polymer adhesive or matrix, a strong bond between the concrete and the FRP is required [96]. The deterioration of the mechanical characteristics of the matrix material at temperatures exceeding $T_{g}$ may cause bond loss even at moderately elevated temperatures, which results in the loss of interaction between the FRP and the concrete. In the literature, there have been a lot of studies on the bond characteristics of FRP bars used for concrete strengthening at high temperatures [47,97-99]. At temperatures between 100 and $200{ }^{\circ} \mathrm{C}$, the bond strength decreases dramatically to approximately $10 \%$ of the room temperature strength because the characteristics of the polymeric matrix at the surface of the rods change. To design concrete members that are reinforced or strengthened 
with FRP, bond deterioration at elevated temperatures is the main factor to consider. Bond strength reductions in the FRP bars at elevated temperatures are commonly evaluated by bond pull-out tests $[23,47]$. A noticeable decrement of the bond strength of FRP bars that are embedded in concrete occurs as the temperature at the bond line rises to within the range of the $T_{g}$ of the bars; considerable bond strength reductions are found at temperatures corresponding to the lowest $T_{g}$ identified for the bars based on the commencement of a decline in the storage modulus of the bars [97].

The durability of the interface bond between concrete and FRP bars was investigated experimentally, with an emphasis on the deterioration of the surface material of the FRP bar when employing a concrete mix with a high compressive strength. For bond strength tests, 48 pull-out samples were cast, consisting of four distinct types of FRP bars. Additional samples were cast for the concrete compressive strength test. The samples were subjected to the following conditions: tap water kept at $60{ }^{\circ} \mathrm{C}$ or room temperature and air that was thermally cycled from -20 to $60{ }^{\circ} \mathrm{C}$. Reductions of $0-20 \%$ in bond strength were seen for GFRP bars and reductions of $4-10 \%$ were reported for CFRP bars after environmental conditioning. Before reaching the peak bond strength, the conditioning increased the free-end slip. It was reported that the deterioration of the bond primarily resulted from the corrosion of the FRP bar and was less due to the concrete [100].

Several numerical studies were also conducted to evaluate the influence of different parameters and predict the performance of FRP-reinforced concrete [100-104]. Yu and Kodur [105] presented numerical studies that investigated the effect of key parameters on the fire response of FRP rebar-reinforced concrete beams. The research was performed with the help of a macroscopic finite element model that considered the high-temperature properties of constitutive materials, actual load, restraint conditions, and the slip between concrete and FRP rebars that was induced by temperature. According to parametric studies, fire scenario, concrete cover thickness, and rebar type all have a substantial impact on the fire response of FRP rebars-reinforced concrete beams, whereas only a minor impact on the existence of axial restraint is observed. These findings of parametric studies are used to recommend the best insulation schemes to improve the fire resistance of FRP rebar-reinforced concrete beams.

\subsubsection{Ultimate Strength}

Some research publications have looked into the strength of various FRP-reinforced elements [28,106,107]. Rafi et al. [108] studied behaviour of GFRP and CFRP bar RC beams at high temperatures. The results of fire testing on six simply supported beams made of normal weight concrete were produced. The impacts of different load levels and different FRP bar types were investigated. Over-reinforced beams were constructed and tested in a floor furnace. The failure criterion for the beam was set at $500{ }^{\circ} \mathrm{C}$ for the rebar. The temperature distribution over the beam cross-section was found to be nonlinear. The change in temperature in the compression concrete was found to be negligible, and its mechanical properties were almost unaffected. All of the beams passed the failure criterion of a critical rebar temperature of $500{ }^{\circ} \mathrm{C}$. At elevated temperatures, the loss of stiffness in the GFRP and steel RC beams was essentially identical and was unaffected by bar modulus or load levels. When compared to other beams, the CFRP bar-reinforced beams had better stiffness characteristics.

Another study found that shear failure is the most common mode of failure in hybrid concrete beam specimens that are reinforced with GFRP when exposed to temperatures ranging from 300 to $700{ }^{\circ} \mathrm{C}$ and subjected to monolithically raised static loads until failure. Around a 53\% reduction in the ultimate load capacity was observed in the hybrid reinforced concrete beam when subjected to $700{ }^{\circ} \mathrm{C}$ in comparison to ambient temperatures, according to the findings [109]. The fatigue performance of GFRP/CFRP bar-reinforced concrete beams after being subjected to elevated temperatures was also evaluated. To assess the fatigue behaviour of beams, the effects of fatigue load level, high temperature, holding time, and FRP bar type were explored. Below $400^{\circ} \mathrm{C}$, the fatigue life of concrete beams 
that were reinforced with GFRP was reduced more severely than that of concrete beams that were reinforced with CFRP, and at $600{ }^{\circ} \mathrm{C}$, the bearing capacities of both CFRP- and GFRP-reinforced beams were lost. With the number of fatigue cycles, the development of concrete strain and fracture width, as well as the deflection of the concrete beams that were reinforced with FRP, was accelerated by the raised temperature [110].

Hajiloo et al. [52] performed fire tests on a full-scale concrete slab that was reinforced with GFRP. The loads were equally distributed, which created a flexural moment of $45 \mathrm{kNm}$. This value was $55 \%$ of the slabs' ultimate moment resistance at ambient temperatures and this flexural moment was maintained throughout the fire test. Both of the loaded slabs were exposed to the ASTM-E119 standard fire for more than three hours. In order to anticipate the deflection behaviour of the FRP-reinforced concrete structures within the range of realistic increased temperatures, Faruqi et al. [111] created a model that incorporates the progressive changes in the elastic modulus of FRP by temperature. The predictions provided by the model were in good agreement with experimental results that were published in the literature. This novel method adds to the tools for assessing the deflection of FRP-reinforced concrete structures in the event of a fire.

Rafi et al. [103] developed a three-dimensional nonlinear finite element model to predict the response of concrete beams that were reinforced with FRP in an elevated temperature regime. The analytical model simulated the propagation of temperature, concrete stresses in beams, and stiffness and strength characteristics. To determine the temperature distribution across the beams, a transient heat transfer analysis was performed. The smeared cracking approach was used for modelling the crack formation and propagation. The models agreed well with the measured temperature, stiffness data, and beam strength; however, its estimation of temperature in sites with a thick concrete layer was conservative.

Lin and Zhang [102] developed a facile two-node layered composite beam element for the accurate simulation of the structural behaviour of steel/FRP-reinforced concrete beams that were subjected to combined thermal and mechanical loading during a fire. The temperature distribution over the cross-section of the beam was determined using a nonlinear finite element analysis based on heat transfer theory. The model was validated using the results presented in [112], and the effects of various parameters on the flexural response of the concrete beams that were reinforced with FRP in fire conditions were also investigated using the current finite element model. These parameters included the level of load, thickness of the concrete cover, and type of FRP reinforcement.

Table 2 summarises the study plan and results that were reported by several researchers on the structural responses of FRP-reinforced concrete members with different types of FRP bars. Different test set-ups were used to study both the ultimate load capacity of the FRP-reinforced concrete members and the bond strength between the FRP bar and the concrete. Figure 4 schematically shows the different set-ups that were used by the researchers. As seen in Table 2 and similar to the results observed in FRP-strengthened concrete structures, the bond strength and the load-carrying capacity of FRP-reinforced concrete members decreases dramatically when the temperature reaches and passes the resin's $T_{g}$. However, it was observed in several studies that under very high temperatures, as well as fire conditions, the structure can still carry a considerable load despite the significant bond strength reduction. This may be due to the fact that FRP bars are embedded in concrete and are not directly exposed to heat and oxygen. 
Table 2. The research plan and results summary of the reported structural responses of FRP-reinforced concrete members with FRP bars.

\begin{tabular}{|c|c|c|c|c|c|c|c|}
\hline Ref & Study Type & Sample & FRP Type & $T_{g}\left({ }^{\circ} \mathrm{C}\right)$ & Exposure Condition & Test Type & Results \\
\hline [99] & $\begin{array}{l}\text { Experimental and } \\
\text { numerical }\end{array}$ & $\begin{array}{l}\text { Sand-coated GFRP } \\
\text { rebars embedded in } \\
\text { concrete cylinders }\end{array}$ & GFRP rebars & $98^{\circ} \mathrm{C}$ & $\begin{array}{l}\text { Tensile: } 20-300^{\circ} \mathrm{C} \text {; and } \\
\text { pull-out test: } 20-140^{\circ} \mathrm{C}\end{array}$ & $\begin{array}{l}\text { Tensile and pull-out } \\
\text { tests (steady-state } \\
\text { conditions) }\end{array}$ & $\begin{array}{l}\text { With the increasing temperature, the } \\
\text { strength and stiffness of the interface of the } \\
\text { GFRP concrete were dramatically reduced, } \\
\text { especially when the } T_{g} \text { of the GFRP rebars } \\
\text { was approached and exceeded. }\end{array}$ \\
\hline [98] & $\begin{array}{l}\text { Experimental and } \\
\text { numerical }\end{array}$ & $\begin{array}{l}\text { A GFRP bar embedded } \\
\text { in the center of a } \\
\text { cylindrical concrete } \\
\text { block }\end{array}$ & GFRP bars & $165^{\circ} \mathrm{C}$ & $20-300{ }^{\circ} \mathrm{C}$ & Pull-out test & $\begin{array}{l}\text { The retained bond strength decreased from } \\
100 \% \text { to } 7.2 \% \text { from } 20^{\circ} \mathrm{C} \text { to } 300^{\circ} \mathrm{C} \text {; the slip } \\
\text { at average bond strength decreased from } \\
0.69 \mathrm{~mm} \text { to } 0.24 \mathrm{~mm} \text {. }\end{array}$ \\
\hline [108] & Experimental & $\begin{array}{l}\text { An FRP bar embedded } \\
\text { in a rectangular } \\
\text { concrete block }\end{array}$ & CFRP and GFRP bars & NA & $20-500{ }^{\circ} \mathrm{C}$ & Four-point bend test & $\begin{array}{l}\text { At elevated temperatures, the stiffness loss } \\
\text { in the GFRP and steel RC beams was } \\
\text { essentially identical and was unaffected by } \\
\text { bar modulus or load levels. When } \\
\text { compared to other beams, the CFRP } \\
\text { bar-reinforced beams had better stiffness } \\
\text { characteristics. }\end{array}$ \\
\hline [110] & $\begin{array}{l}\text { Experimental and } \\
\text { numerical }\end{array}$ & $\begin{array}{l}\text { FRP-reinforced } \\
\text { rectangular concrete } \\
\text { beams }\end{array}$ & CFRP and GFRP bars & $\begin{array}{l}\text { GFRP: } 155^{\circ} \mathrm{C} \\
\text { CFRP: } 139^{\circ} \mathrm{C}\end{array}$ & $200-600^{\circ} \mathrm{C}$ & $\begin{array}{c}\text { Fatigue test } \\
\text { (four-point bending) }\end{array}$ & $\begin{array}{l}\text { The fatigue strength of the beams was } \\
\text { reduced from } 0.12 \text { ultimate load to } \\
0.10 \text { ultimate load after being exposed to } \\
400{ }^{\circ} \mathrm{C} \text { for } 2 \mathrm{~h} \text {. With a coefficient of } \\
\text { variation of } 2.8-7.0 \% \text {, the CEB-FIP model } \\
\text { had the best accuracy. }\end{array}$ \\
\hline
\end{tabular}


Table 2. Cont.

\begin{tabular}{|c|c|c|c|c|c|c|c|}
\hline Ref & Study Type & Sample & FRP Type & $T_{g}\left({ }^{\circ} \mathrm{C}\right)$ & Exposure Condition & Test Type & Results \\
\hline [52] & Experimental & $\begin{array}{c}\text { A full-scale } \\
\text { FRP-reinforced concrete } \\
\text { slab }\end{array}$ & GFRP bars & $113,118^{\circ} \mathrm{C}$ & Fire test for $3 \mathrm{~h}$ & Bending test & $\begin{array}{l}\text { Under flexural pressure, the reinforced } \\
\text { slabs had a fire endurance of almost } 3 \mathrm{~h} \text {. At } \\
\text { temperatures around the } T_{g} \text { of the bars, the } \\
\text { majority of the bond strength was lost. } \\
\text { Despite the fact that the adhesive in the } \\
\text { reinforcing bars was entirely burnt, none } \\
\text { of the reinforcing bars ruptured. }\end{array}$ \\
\hline [114] & $\begin{array}{l}\text { Experimental and } \\
\text { numerical }\end{array}$ & $\begin{array}{c}\text { A GFRP rebar } \\
\text { embedded in cylindrical } \\
\text { concrete }\end{array}$ & GFRP rebars & $104,157^{\circ} \mathrm{C}$ & $25-300^{\circ} \mathrm{C}$ & $\begin{array}{l}\text { Steady-state tensile } \\
\text { and pull-out tests }\end{array}$ & $\begin{array}{l}\text { The ribbed rebars showed bond strength } \\
\text { losses ranging from } 20 \% \text { to } 34 \% \text {, while the } \\
\text { sand-coated rebars had a reduction of } 81 \% \text {; } \\
\text { at temperatures above the rebars' } T_{g} \text {, the } \\
\text { majority of the GFRP-concrete interaction } \\
\text { in the ribbed rebars was reduced. }\end{array}$ \\
\hline [115] & Experimental & $\begin{array}{l}\text { A GFRP rebar } \\
\text { embedded in } \\
\text { rectangular concrete }\end{array}$ & $\begin{array}{l}\text { GFRP and CFRP rebars } \\
\text { with sand coating } \\
\text { treatment }\end{array}$ & $120^{\circ} \mathrm{C}$ & $\begin{array}{l}\text { Fire, up to } 1000^{\circ} \mathrm{C} \text { for } \\
2 \mathrm{~h}\end{array}$ & Four-point bend test & $\begin{array}{l}\text { The concrete beam that were reinforced } \\
\text { with carbon and glass rebars of diameters } \\
10 \mathrm{~mm} \text { and } 14 \mathrm{~mm} \text { reached } 66 \%, 31 \% \text {, and } \\
46 \% \text { of their initial load-bearing capacities, } \\
\text { respectively. }\end{array}$ \\
\hline [116] & Experimental & $\begin{array}{l}\text { FRP-reinforced concrete } \\
\text { beams }\end{array}$ & $\begin{array}{l}\text { BFRP, hybrid FRP with } \\
\text { basalt and carbon fibres } \\
\text { (HFRP), and } \\
\text { nano-hybrid FRP } \\
\text { (nHFRP) }\end{array}$ & NA & Fire & $\begin{array}{l}\text { Post fire: four-point } \\
\text { bend test }\end{array}$ & $\begin{array}{l}\text { After being exposed to fire, a reduction in } \\
\text { the overall strength capacity of the } \\
\text { FRP-reinforced beams was observed by } \\
\text { approximately } 43 \%, 40 \% \text {, and } 43 \% \text { for the } \\
\text { beams with tensile zones that were } \\
\text { reinforced with BFRP bars, HFRP bars, and } \\
\text { nHFRP bars, respectively. }\end{array}$ \\
\hline
\end{tabular}




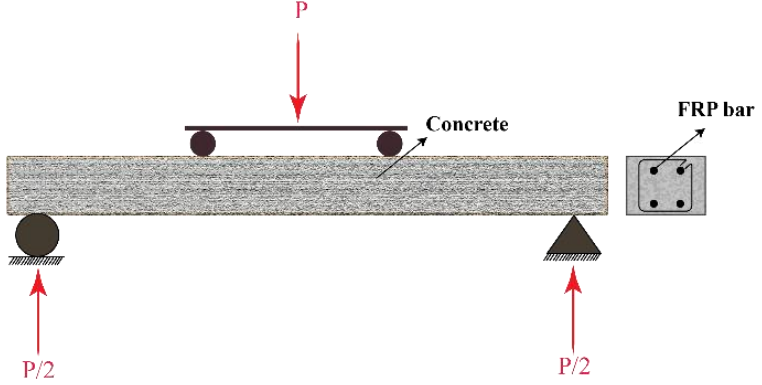

(a)

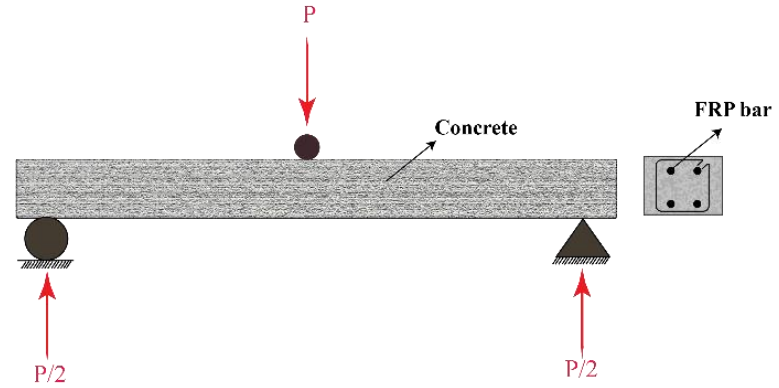

(b)

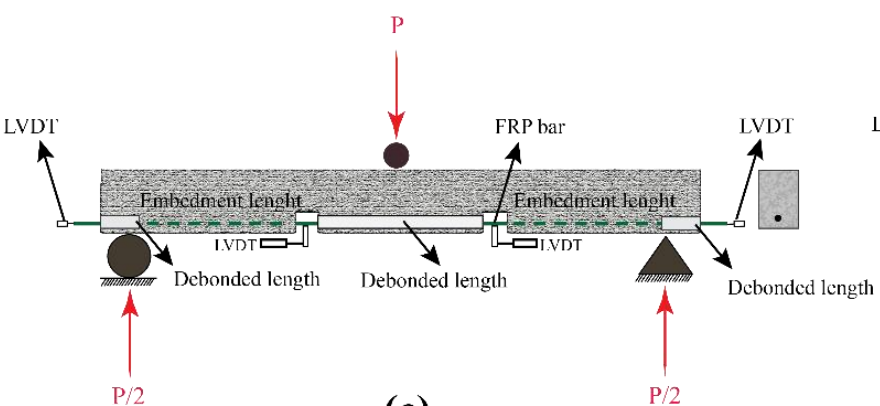

(c)
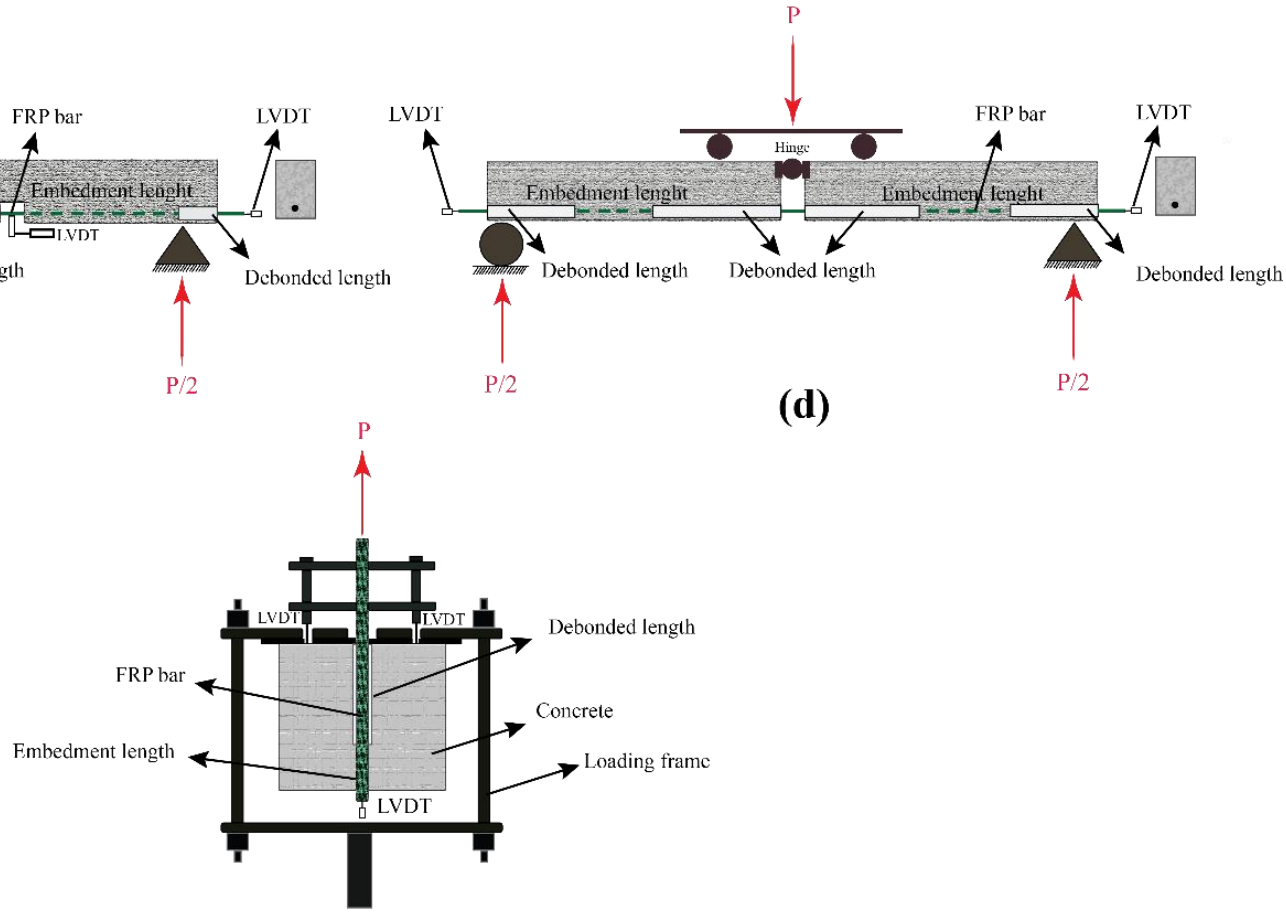

(d)

(e)

Figure 4. The set-ups that were used to test FRP-reinforced concrete: (a) ultimate strength four-point bend; (b) ultimate strength three-point bend; (c) bond strength three-point bend; (d) bond strength four-point bend; and (e) direct pull-out. Reproduced from [14], with permission from Elsevier, 2022.

\subsection{FRP-Wrapped Concrete Members}

Over the past two decades, research projects all over the world have studied the behaviour of externally bonded FRPs that were used for reinforcing RC structures. The exterior of the RC structures is connected to FRPs, often with an epoxy resin adhesive, which provides extra tensile or confining reinforcement, in addition to the internal reinforcing steel. There has now been enough study and execution to produce numerous guidelines and design codes for using FRPs in conjunction with concrete structures $[117,118]$. In several studies, it has been demonstrated that external FRP wraps on RC columns could greatly improve the strength, as well as the ductility, of these elements $[119,120]$. As a result, FRPs have been widely used for repairing and restoring RC columns in existing bridges. However, the use of FRP wraps in structures has been limited by concerns about their performance in the case of fire. The majority of FRPs are sensitive to the combustion of the polymer matrix, which can result in the enhanced spread of flames and harmful smoke emissions. Furthermore, at their $T_{g}$, the rapid loss of stiffness and strength occurs in commonly used adhesives and polymer matrices. For externally bonded 
systems, the crucial $T_{g}$ depends on the individual polymer matrix composition, among other considerations. FRPs may ignite and facilitate the propagation of flames and the production of poisonous smoke if left unprotected in a fire [8], and also rapidly lose bond and/or mechanical performance. This could raise questions about the fire resistance of FRP-strengthened RC columns in buildings where fire is a major design consideration [121].

As a result, much more research is needed to fully comprehend the performance of structures that are strengthened with FRPs in terms of fire resistance. Al-Salloum et al. [121] investigated the behaviour of concrete that was externally confined with CFRP and GFRP sheets using uniaxial compression at high temperatures (exposure time of 1,2 or $3 \mathrm{~h}$ at $100{ }^{\circ} \mathrm{C}$ and $200{ }^{\circ} \mathrm{C}$ ). The results showed that, at slightly above the $T_{g}$ of the epoxy resin $\left(100{ }^{\circ} \mathrm{C}\right)$, a small loss in strength occurred in both GFRP- and CFRPwrapped specimens, which resulted from the epoxy melting. At $200{ }^{\circ} \mathrm{C}$, the strength loss was more noticeable. The efficiency of the FRP confining system that was bonded with epoxy diminished significantly (under a steady-state thermal regime and concentric axial compression), but did not vanish as the temperature increased, particularly in the region of the epoxy resin/adhesive $T_{g}$ [122].

A numerical model for the prediction of the response of FRP-wrapped RC circular columns with thermal insulation to fire was developed by Bisby et al. [31]. The model took into account the temperature-dependent fluctuation of thermo-physical characteristics and consisted of two stages: first, an analysis of finite difference heat transfer; second, an analysis of strain-equilibrium axial load capacity, which was calculated during standard fire exposure. They made the assumption of axisymmetric heat transport and ignored the heating effect of steel rebars. Buckling and crushing strengths were calculated by accounting for the temperature-dependent stress-strain compressive response of concrete along with the FRP wrap-induced confining pressure, using a modified version of Spoelstra and Monti's confinement model [123]. The output contained load vs. mid-height deflection charts for a variety of fire exposure durations, indicating the axial capacity vs. time relationship. Experimental data reported by Bisby et al. [124] were utilised to validate the model, which was demonstrated to be capable of predicting the axial deflection and temperature profiles of the columns after fire exposure. Chowdhury et al. [125] further validated this model using data from furnace tests on insulated RC columns that were wrapped with FRP. There was a good match between the expected and measured temperatures. Chowdhury et al. [126] modified the previous model to include the structural behaviour of short or thin, eccentrically or concentrically loaded FRP-wrapped RC rectangular columns in both ambient and fire environments. The heat transfer analysis was performed using a finite difference approach that was similar to that employed by Bisby et al. [31].

Table 3 summarises the study plan and results that were reported by several researchers on the structural responses of FRP-wrapped concrete members with different types of FRP sheets. The compressive load-carrying capacity and the efficiency of the FRP wrapping were studied by different researchers. Figure 5 shows the test set-ups that were used by the different researchers to study the compressive strength and bond strength of FRP-wrapped concrete columns and concrete filled FRP tubes. From the reported results, it can be concluded that the efficiency of FRP wrapping on the compressive load-carrying capacity of concrete columns under elevated temperatures depends on the fibre type and the number of applied layers. In terms of the FRP layers, it was reported in [122] that, under elevated temperatures, the efficiency of three layers of CFRP wrapping was higher than one layer. In terms of the fibre type, although it was shown in [127] that CFRP-wrapped concrete columns had a better compressive performance compared to the GFRP-wrapped columns, more studies are required to clearly understand the effect of different fibres, particularly GFRP and BFRP. It is also worth mentioning that the effect of fibre orientation could be considered as a potential factor in studying the compressive performance of FRP-wrapped concrete columns under elevated temperatures. 
Table 3. The research plan and results summary of the reported structural responses of FRP-wrapped concrete members with FRP sheets.

\begin{tabular}{|c|c|c|c|c|c|c|c|}
\hline Ref & Study Type & Sample & FRP Type & $T_{g}\left({ }^{\circ} \mathrm{C}\right)$ & Exposure Condition & Test Type & Results \\
\hline [122] & Experimental & $\begin{array}{l}\text { FRP-wrapped } \\
\text { cylindrical concrete } \\
\text { (hoop direction) }\end{array}$ & $\begin{array}{c}\text { CFRP sheet ( } 1 \text { and } \\
3 \text { layers) }\end{array}$ & $58^{\circ} \mathrm{C}$ & $\begin{array}{l}20-400{ }^{\circ} \mathrm{C}(\mathrm{a} \\
\text { steady-state thermal } \\
\text { regime })\end{array}$ & $\begin{array}{l}\text { Concentric axial } \\
\text { compression }\end{array}$ & $\begin{array}{l}\text { At ambient temperatures, the strength } \\
\text { effectiveness }\left(f_{c c} / f_{c o}\right) \text { of a single layer of FRP } \\
\text { was approximately } 2.02 \text {. As the temperature } \\
\text { increased, the efficiency of the confinement } \\
\text { was reduced. At } 150{ }^{\circ} \mathrm{C} \text {, the single FRP } \\
\text { layer's efficacy was at its lowest }(1.13) \text {. The } \\
f_{c c} / f_{c o} \text { values for FRP jacketing were } 3.89 \text { in } \\
\text { the case of three layers at ambient } \\
\text { temperature. At } 400^{\circ} \mathrm{C} \text {, the minimum } \\
\text { effectiveness for three FRP layers was } 2.39 \text {. }\end{array}$ \\
\hline [128] & $\begin{array}{l}\text { Experimental and } \\
\text { numerical }\end{array}$ & $\begin{array}{l}\text { FRP-confined square } \\
\text { concrete prisms } \\
\text { (hoop direction) }\end{array}$ & $\begin{array}{c}\text { BFRP sheet }(2,3 \text {, and } \\
4 \text { layers })\end{array}$ & NA & $200-800^{\circ} \mathrm{C}$ & $\begin{array}{c}\text { Axial compression } \\
\text { test }\end{array}$ & $\begin{array}{l}\text { The tensile rupture of the BFRP jackets was } \\
\text { the cause of the failure. The use of BFRP } \\
\text { jackets was shown to improve the ultimate } \\
\text { axial strain and compressive strength of } \\
\text { heat-damaged concrete. The concrete core } \\
\text { coated in additional BFRP jacket layers had a } \\
\text { greater increase in deformation and strength. }\end{array}$ \\
\hline [127] & $\begin{array}{c}\text { Experimental and } \\
\text { numerical }\end{array}$ & $\begin{array}{l}\text { FRP-wrapped } \\
\text { circular columns }\end{array}$ & $\begin{array}{l}\text { CFRP and GFRP } \\
\text { sheets (1 layer) }\end{array}$ & NA & $20-300{ }^{\circ} \mathrm{C}$ for $1-3 \mathrm{~h}$ & $\begin{array}{l}\text { Uniaxial } \\
\text { compression test }\end{array}$ & $\begin{array}{c}\text { The wrapped CFRP and GFRP specimens lost } \\
\text { about } 25.3 \% \text { and } 37.9 \% \text { of their compressive } \\
\text { strength after } 3 \mathrm{~h} \text { of exposure to } 300{ }^{\circ} \mathrm{C} \text {, } \\
\text { respectively. }\end{array}$ \\
\hline [126] & $\begin{array}{l}\text { Experimental and } \\
\text { numerical }\end{array}$ & $\begin{array}{l}\text { FRP-wrapped } \\
\text { rectangular columns }\end{array}$ & CFRP sheet (1 layer) & NA & Fire & $\begin{array}{l}\text { Uniaxial } \\
\text { compression test }\end{array}$ & $\begin{array}{l}\text { Under ambient and fire conditions, a novel } \\
\text { computer model was developed to predict } \\
\text { several aspects of the structural and thermal } \\
\text { response of uninsulated or insulated, slender } \\
\text { or short, FRP-wrapped or unwrapped, and } \\
\text { eccentrically or concentrically loaded } \\
\text { reinforced concrete columns. }\end{array}$ \\
\hline
\end{tabular}


Table 3. Cont.

\begin{tabular}{|c|c|c|c|c|c|c|c|}
\hline Ref & Study Type & Sample & FRP Type & $T_{g}\left({ }^{\circ} \mathrm{C}\right)$ & Exposure Condition & Test Type & Results \\
\hline [130] & $\begin{array}{l}\text { Numerical } \\
\text { (artificial neural } \\
\text { networks) }\end{array}$ & $\begin{array}{l}\text { FRP-confined } \\
\text { concrete column }\end{array}$ & NA & NA & Fire & ANSYS software & $\begin{array}{l}\text { With an overall accuracy of } 85-90 \% \text {, the } \\
\text { suggested ANN model could predict FRP, } \\
\text { concrete, and steel reinforcement and the } \\
\text { temperature during fire exposure. }\end{array}$ \\
\hline [131] & $\begin{array}{l}\text { Experimental and } \\
\text { numerical }\end{array}$ & $\begin{array}{c}\text { FRP-wrapped } \\
\text { circular and square } \\
\text { columns + insulation } \\
\text { layer }\end{array}$ & CFRP sheet (1 layer) & $85^{\circ} \mathrm{C}$ & Fire & $\begin{array}{l}\text { Full-scale fire } \\
\text { resistance test + } \\
\text { FORTRAN }\end{array}$ & $\begin{array}{l}\text { Both columns had fire resistance ratings of } \\
\text { more than } 4 \mathrm{~h} \text {. The validation of the } \\
\text { numerical models created, particularly for } \\
\text { circular and square columns, was carried out } \\
\text { using experimental results. }\end{array}$ \\
\hline [132] & Experimental & $\begin{array}{l}\text { Insulated } \\
\text { FRP-wrapped square } \\
\text { RC columns }\end{array}$ & CFRP sheet (1 layer) & NA & Fire & $\begin{array}{l}\text { Full-scale fire } \\
\text { resistance } \\
\text { experiments }\end{array}$ & $\begin{array}{l}\text { Fire endurance of } 4 \mathrm{~h} \text { or more was achieved } \\
\text { with FRP-strengthened square } \mathrm{RC} \text { columns } \\
\text { protected with the fire protection system } \\
\text { mentioned here. }\end{array}$ \\
\hline
\end{tabular}




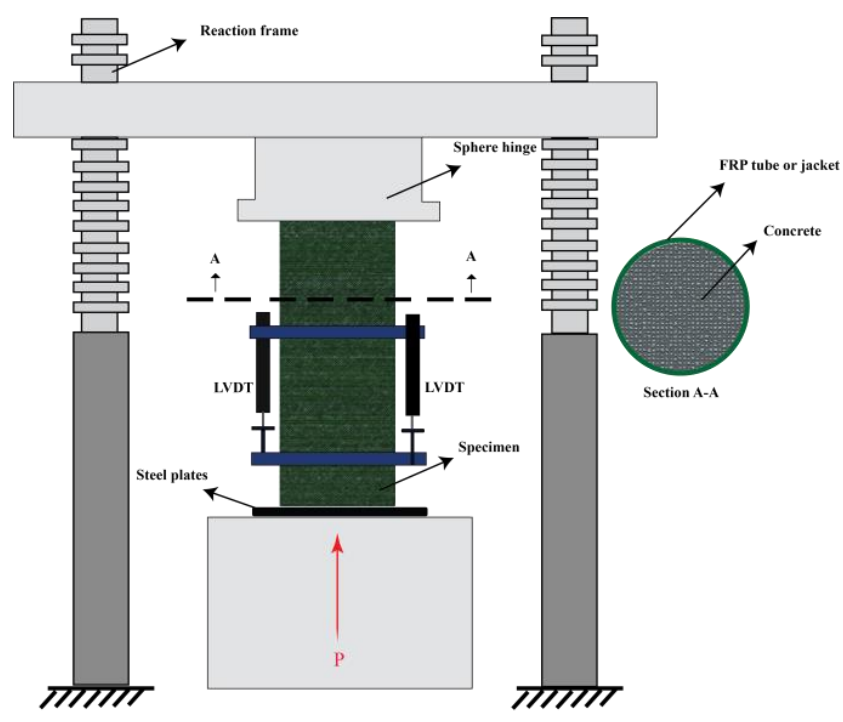

(a)

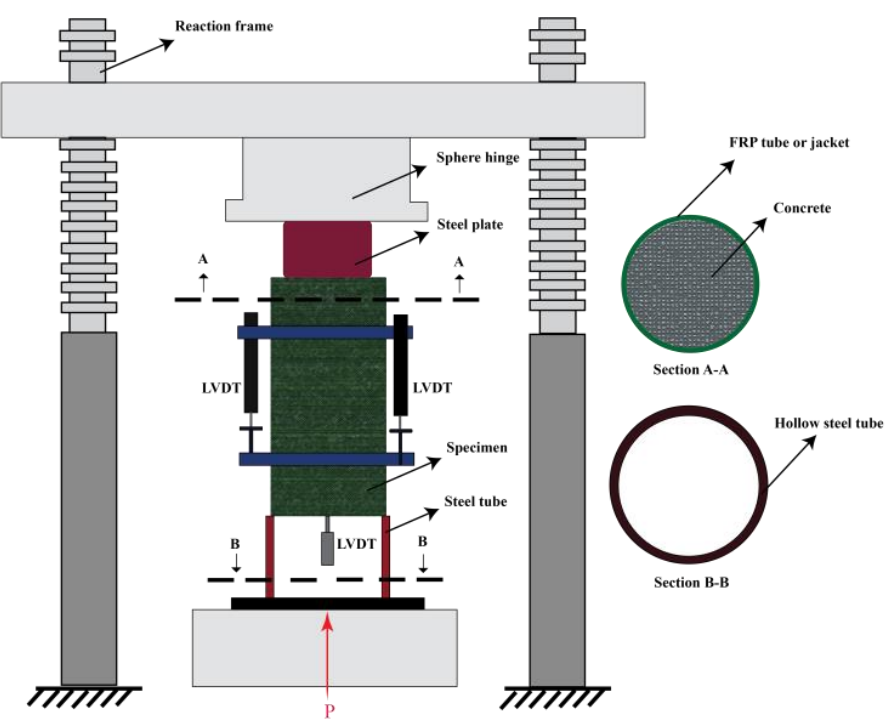

(b)

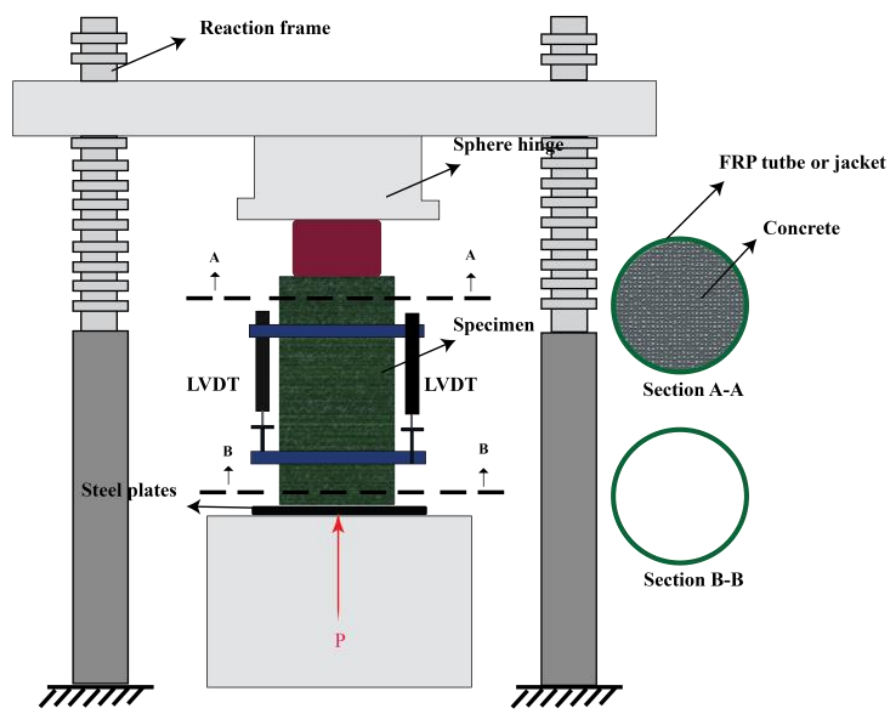

(c)

Figure 5. The set-ups that were used to test FRP-wrapped concrete columns and concrete filled FRP tubes: (a) compressive; (b) push-out test set-up type 1; and (c) push-out test set-up type 2. Reproduced from [14], with permission from Elsevier, 2022.

\subsection{Concrete Filled FRP Tubes}

It is well-known that, in harsh environments, carbon steel tubes are highly susceptible to being corroded after prolonged contact with acid rain, seawater, and other aggressive agents $[38,133]$. To address such concerns, corrosion-resistant FRP tubes filled with concrete have recently been employed [134-136]. Although there are numerous reports addressing the performance of reinforced concrete with FRP bars and externally bounded laminates, as well as FRP-wrapped concrete elements, at elevated temperatures, very few studies have investigated the behaviour of concrete filled FRP tubes at high temperatures. Guo et al. [137] investigated the mechanical characteristics of short, pultruded concrete filled GFRP tubular (CFGT) columns under axial compressive loading at extreme temperatures. Axial testing was performed on short CFGT columns that were subjected to various high temperatures and temperature durations. The concrete compressive strength, GFRP tube thickness, elevated temperature, and temperature duration were the primary variables that were investigated in this work. The findings of the experiments showed that when 
the temperature rose, the initial stiffness and ultimate strength of the samples decreased significantly whereas ductility increased. When the temperature approached $200{ }^{\circ} \mathrm{C}$, the ultimate strengths of the samples were significantly reduced (approximately 37\%). The impact of elevated temperatures on the specimens' ultimate strength was the most significant among the four main factors, whereas the concrete compressive strength and GFRP tube thickness had some positive impacts, and the effect of temperature duration was negligible. According to the findings of the experiments, a parameter formula for calculating the ultimate strength of the short columns at elevated temperatures was produced, which demonstrated high rationality and accuracy when compared to the test results.

In a similar study conducted by Tabatabaeian et al. [138], the properties of concrete filled pultruded GFRP tubular columns were also assessed at high temperatures. The goal of this study was to see how exposure temperature $\left(25-400^{\circ} \mathrm{C}\right)$, exposure time (60 and $120 \mathrm{~min}$ ), and the strength of the concrete core (30 and $60 \mathrm{MPa}$ ) affected the bond and compressive behaviour of CFGTs. Split disk and compressive tests were used to investigate the performance of unexposed and exposed concrete cores, pultruded GFRP hollow tubes, and CFGTs. To determine the bond-slip strength of the partially filled specimens, the push-out test was also used. The maximum load-bearing capability of stub columns exposed to elevated temperatures was $8 \%, 22 \%, 34 \%$, and $51 \%$ lower than the unexposed counterparts at temperatures of $100,200,300$, and $400{ }^{\circ} \mathrm{C}$, respectively. The GFRP tubes withstood around one quarter of the overall load-bearing capability, regardless of the core strength or exposure conditions. Furthermore, it was discovered that when the exposure temperature and concrete core strength increased, the final axial strain (related to tube rupture) of the column samples decreased; however, the ultimate axial strain was not affected by exposure time. To develop novel models for predicting experimental outcomes, the dilation and load-bearing capability of CFGTs were studied. In terms of bond strength testing, it was determined that increasing the exposure temperature increased interlocking and thus, the coefficient of kinetic friction, which resulted in increased bond strength. Eventually, equations for estimating the bond strength of CFGTs after being exposed to high temperatures were presented.

\section{Summary}

A systematic overview and discussion regarding the structural performance of FRPreinforced/strengthened concrete members after exposure to elevated temperatures was presented. Although FRP-reinforced/strengthened concrete members provide many benefits, their vulnerability to elevated temperatures remains a challenging concern. By reviewing the research conducted on concrete strengthened with FRP composites, one can conclude that their performance when subjected to elevated temperatures is well studied. In addition to the experimental data, analytical models have been developed to predict tensile and bond strength reductions of FRPs at elevated temperatures. In terms of the bond between FRPs and concrete, it has been shown that the thermal loading affects the bond behaviour through influencing (i) the stress transmission between the FRP and the concrete and (ii) the load-bearing capacity provided by the FRP system. It is generally observed that the degradation of the resin's mechanical characteristics at temperatures exceeding $T_{g}$ may result in bond loss, even at moderately elevated temperatures (e.g., $90 \%$ bond strength reduction at temperatures between 100 and $200{ }^{\circ} \mathrm{C}$ ), which results in the loss of FRP-concrete interaction. Significant ultimate strength reductions also occur when FRP-reinforced beams are exposed to fire (e.g., 53\% flexural strength reduction of GFRP reinforced concrete beam exposed to $700{ }^{\circ} \mathrm{C}$ ). However, the retention is significantly affected by the concrete cover, FRP bar type and diameter, and the thermal properties of the components. Given the discussion and findings presented in this review, more experimental and numerical studies are needed to develop comprehensive predictive models that are capable of predicting the structural performance of FRP-reinforced/strengthened concrete when exposed to elevated temperatures. The present paper provided a fundamental insight 
that could be used to develop or enhance new and existing design codes/standards for FRP-reinforced/strengthened structures.

\section{Recommendations for Future Studies}

Sufficient implementations and investigations have now been conducted to develop numerous guidelines and design codes for the application of FRPs in conjunction with concrete structures. Following the discussion presented in this paper, it can be concluded that more experimental and numerical research studies are required to address several research gaps regarding the performance of FRP-reinforced/strengthened concrete members under elevated temperatures. The following research topics are therefore recommended for future studies to fill some of these gaps:

(1) Applying cyclic and impact loading to FRP-reinforced/strengthened concrete members under elevated temperatures in order to study their dynamic behaviour after exposure to elevated temperatures. Currently, most studies have been conducted under static loading.

(2) The current experimental data can be used to verify/calibrate finite element numerical models and then comprehensive parametric studies can be conducted to investigate the effects of different parameters, such as material thermal and mechanical characteristics, resin curing ratio, fibre type and orientation, heating rate, etc.

(3) Conducting tests using real fire. Currently, most studies have been conducted under electrical furnace conditions. It is expected that the performance of structural members under real fire conditions may be significantly different from that of simulated standard fire testing.

(4) Studies on concrete filled FRP tubes under elevated temperatures are very limited. Therefore, several effective parameters, such as fibre type and orientation, tube geometry (e.g., dimeter to thickness ratio), surface friction coefficient (in the case of studying the bond between the concrete and the tube), etc. are yet to be investigated.

(5) Conducting full-scale tests to investigate the effect of stress redistribution and structure size effect.

Author Contributions: F.S.: Writing—original draft preparation, writing—review and editing, formal analysis, software, and resources. P.Z.: Writing-review and editing, formal analysis, software, and resources. M.B.: Writing—review and editing, formal analysis, software, supervision, and resources. A.E.: Writing-review and editing, formal analysis, software, and resources. R.R.: Writing-review and editing, formal analysis, software, and resources. L.B.: Writing-review and editing, formal analysis, software, and resources. S.K.: Writing-review and editing, formal analysis, and resources. All authors have read and agreed to the published version of the manuscript.

Funding: This research received no external funding.

Institutional Review Board Statement: Not applicable.

Informed Consent Statement: Not applicable.

Data Availability Statement: The data presented in this study are available on request from the corresponding author.

Conflicts of Interest: The authors declare no conflict of interest.
Abbreviations
FRP
fibre-reinforced polymer
GFRP glass fibre-reinforced polymer
BFRP basalt fibre-reinforced polymer
CFRP carbon fibre-reinforced polymer
HFRP hybrid fibre-reinforced polymer 


$\begin{array}{ll}\text { NSM } & \text { near-surface mounted } \\ \text { PC } & \text { prestressed concrete } \\ \text { DSC } & \text { differential scanning calorimetry } \\ \text { DMA } & \text { dynamic mechanical analyses } \\ T_{g} & \text { glass transition temperature } \\ T_{d} & \text { decomposition temperature } \\ \text { PBO } & \text { polybenzoxazole } \\ \text { RC } & \text { reinforced concrete } \\ \text { VG } & \text { vermiculite gypsum } \\ \text { C-S-H } & \text { calcium-silica-hydrate } \\ \mathrm{C}_{2} \mathrm{~S} & \text { dicalcium silicate } \\ \text { CTE } & \text { thermal expansion coefficient } \\ \text { RA } & \text { rectangular recycled aggregate } \\ f_{c c} & \text { peak stress sustained by the confined concrete cylinder } \\ f_{c o} & \text { concrete only strength of the control cylinder } \\ \text { CFGT } & \text { concrete filled GFRP tubular } \\ \text { EBR } & \text { externally bonded reinforcement }\end{array}$

\section{References}

1. Bisby, L.A.; Green, M.F.; Kodur, V.K. Response to fire of concrete structures that incorporate FRP. Prog. Struct. Eng. Mater. 2005, 7, 136-149. [CrossRef]

2. Oskouei, A.V.; Jafari, A.; Bazli, M.; Ghahri, R. Effect of different retrofitting techniques on in-plane behavior of masonry wallettes. Constr. Build. Mater. 2018, 169, 578-590. [CrossRef]

3. Bazli, M.; Zhao, X.-L.; Raman, R.S.; Bai, Y.; Al-Saadi, S. Bond performance between FRP tubes and seawater sea sand concrete after exposure to seawater condition. Constr. Build. Mater. 2020, 265, 120342. [CrossRef]

4. Jafari, A.; Ashrafi, H.; Bazli, M.; Ozbakkaloglu, T. Effect of thermal cycles on mechanical response of pultruded glass fiber rein-forced polymer profiles of different geometries. Compos. Struct. 2019, 223, 110959. [CrossRef]

5. Cao, S.; Wu, Z.; Wang, X. Tensile Properties of CFRP and Hybrid FRP Composites at Elevated Temperatures. J. Compos. Mater. 2009, 43, 315-330. [CrossRef]

6. Mouritz, A.P.; Gibson, A.G. Fire Properties of Polymer Composite Materials; Springer Science \& Business Media: Berlin/Heidelberg, Germany, 2007.

7. Wang, K.; Young, B.; Smith, S. Mechanical properties of pultruded carbon fibre-reinforced polymer (CFRP) plates at elevated temperatures. Eng. Struct. 2011, 33, 2154-2161. [CrossRef]

8. Najafabadi, E.P.; Bazli, M.; Ashrafi, H.; Oskouei, A.V. Effect of applied stress and bar characteristics on the short-term creep be-havior of FRP bars. Constr. Build. Mater. 2018, 171, 960-968. [CrossRef]

9. Jafari, A.; Oskouei, A.V.; Bazli, M.; Ghahri, R. Effect of the FRP sheet's arrays and NSM FRP bars on in-plane behavior of URM walls. J. Build. Eng. 2018, 20, 679-695. [CrossRef]

10. Oskouei, A.V.; Kivi, M.P.; Araghi, H.; Bazli, M. Experimental study of the punching behavior of GFRP reinforced lightweight concrete footing. Mater. Struct. 2017, 50, 256. [CrossRef]

11. Chowdhury, E.; Eedson, R.; Bisby, L.; Green, M.; Benichou, N. Mechanical characterization of fibre reinforced polymers materials at high temperature. Fire Technol. 2011, 47, 1063-1080. [CrossRef]

12. Yu, B.; Kodur, V. Effect of temperature on strength and stiffness properties of near-surface mounted FRP reinforcement. Compos. Part B Eng. 2014, 58, 510-517. [CrossRef]

13. Miller, J.; Weaver, P. Temperature profiles in composite plates subject to time-dependent complex boundary conditions. Compos. Struct. 2003, 59, 267-278. [CrossRef]

14. Bazli, M.; Heitzmann, M.; Hernandez, B.V. Hybrid fibre reinforced polymer and seawater sea sand concrete structures: A sys-tematic review on short-term and long-term structural performance. Constr. Build. Mater. 2021, 301, 124335. [CrossRef]

15. Sweeting, R.; Liu, X. Measurement of thermal conductivity for fibre-reinforced composites. Compos. Part A Appl. Sci. Manuf. 2004, 35, 933-938. [CrossRef]

16. Bascom, W.D.; Cottington, R.L. Effect of Temperature on the Adhesive Fracture Behavior of an Elastomer-Epoxy Resin. J. Adhes. 1976, 7, 333-346. [CrossRef]

17. Phan, L.T.; Carino, N.J. Review of Mechanical Properties of HSC at Elevated Temperature. J. Mater. Civ. Eng. 1998, 10, 58-65. [CrossRef]

18. Ashrafi, H.; Bazli, M.; Oskouei, A.V. Enhancement of bond characteristics of ribbed-surface GFRP bars with concrete by using carbon fiber mat anchorage. Constr. Build. Mater. 2017, 134, 507-519. [CrossRef]

19. Naser, M.; Hawileh, R.; Abdalla, J. Fiber-reinforced polymer composites in strengthening reinforced concrete structures: A criti-cal review. Eng. Struct. 2019, 198, 109542. [CrossRef] 
20. Chalioris, C.E.; Kosmidou, P.-M.K.; Papadopoulos, N.A. Investigation of a New Strengthening Technique for RC Deep Beams Using Carbon FRP Ropes as Transverse Reinforcements. Fibers 2018, 6, 52. [CrossRef]

21. Belarbi, A.; Bae, S.-W.; Brancaccio, A. Behavior of full-scale RC T-beams strengthened in shear with externally bonded FRP sheets. Constr. Build. Mater. 2012, 32, 27-40. [CrossRef]

22. A.C.I. 440, Guide for the Design and Construction of Concrete Reinforced with FRP Bars: ACI 440.1 R-03; American Concrete Institute: Farmington Hills, MI, USA, 2003; Available online: https:/ / www.concrete.org/publications/internationalconcreteabstractsportal/ $\mathrm{m} /$ details/id/12639 (accessed on 25 December 2021).

23. Blontrock, H.; Taerwe, L.; Matthys, S. Properties of fiber reinforced plastics at elevated temperatures with regard to fire re-sistance of reinforced concrete members. Spec. Publ. 1999, 188, 43-54.

24. Zhu, H.; Wu, G.; Zhang, L.; Zhang, J.; Hui, D. Experimental study on the fire resistance of RC beams strengthened with near-surface-mounted high-Tg BFRP bars. Compos. Part B Eng. 2014, 60, 680-687. [CrossRef]

25. Khaneghahi, M.H.; Najafabadi, E.P.; Bazli, M.; Oskouei, A.V.; Zhao, X.-L. The effect of elevated temperatures on the compres-sive section capacity of pultruded GFRP profiles. Constr. Build. Mater. 2020, 249, 118725. [CrossRef]

26. Jiangtao, Y.; Yichao, W.; Kexu, H.; Kequan, Y.; Jianzhuang, X. The performance of near-surface mounted CFRP strengthened RC beam in fire. Fire Saf. J. 2017, 90, 86-94. [CrossRef]

27. Bazli, M.; Jafari, A.; Ashrafi, H.; Zhao, X.-L.; Bai, Y.; Raman, R.S. Effects of UV radiation, moisture and elevated temperature on mechanical properties of GFRP pultruded profiles. Constr. Build. Mater. 2020, 231, 117137. [CrossRef]

28. Nigro, E.; Cefarelli, G.; Bilotta, A.; Manfredi, G.; Cosenza, E. Fire resistance of concrete slabs reinforced with FRP bars. Part I: Experimental investigations on the mechanical behavior. Compos. Part B Eng. 2011, 42, 1739-1750. [CrossRef]

29. Bai, Y.; Keller, T. Time Dependence of Material Properties of FRP Composites in Fire. J. Compos. Mater. 2009, 43, 2469-2484. [CrossRef]

30. Kodur, V.K.R.; Bisby, L.A.; Green, M. Preliminary Guidance for the Design of FRP-strengthened Concrete Members Exposed to Fire. J. Fire Prot. Eng. 2007, 17, 5-26. [CrossRef]

31. Bisby, L.A.; Green, M.; Kodur, V.K.R. Modeling the Behavior of Fiber Reinforced Polymer-Confined Concrete Columns Exposed to Fire. J. Compos. Constr. 2005, 9, 15-24. [CrossRef]

32. Vinson, J.R.; Sierakowski, R.L.; Bert, C.W. The Behavior of Structures Composed of Composite Materials. J. Appl. Mech. 1987, 54, 249. [CrossRef]

33. Hamad, R.J.; Johari, M.M.; Haddad, R.H. Mechanical properties and bond characteristics of different fiber reinforced polymer rebars at elevated temperatures. Constr. Build. Mater. 2017, 142, 521-535. [CrossRef]

34. Wang, Y.C.; Wong, P.M.H.; Kodur, V. An experimental study of the mechanical properties of fibre reinforced polymer (FRP) and steel reinforcing bars at elevated temperatures. Compos. Struct. 2007, 80, 131-140. [CrossRef]

35. Deuring, M. Fire tests on strengthened reinforced concrete beams. Res. Rep. 1994, 795.

36. Williams, B.; Kodur, V.; Green, M.; Bisby, L. Fire Endurance of Fiber-Reinforced Polymer Strengthened Concrete T-Beams. ACI Struct. J. 2008, 105, 60-67. [CrossRef]

37. Masuelli, M.A. Introduction of fibre-reinforced polymers-polymers and composites: Concepts, properties and processes. In Fiber Reinforced Polymers-The Technology Applied for Concrete Repair; IntechOpen: London, UK, 2013; Available online: https:/ / www.intechopen.com/books / fiber-reinforced-polymers-the-technology-applied-for-concrete-repair/introduction-offibre-reinforced-polymers-polymers-and-composites-concepts-properties-and-processes (accessed on 25 December 2021).

38. Bazli, M. Mechanical and Microstructural Properties of Different FRP Composites under Various Environmental Conditions. Ph.D. Thesis, Monash University, Melbourne, VI, Australia, 2020.

39. Bazli, M.; Zhao, X.-L.; Jafari, A.; Ashrafi, H.; Raman, R.S.; Bai, Y.; Khezrzadeh, H. Durability of glass-fibre-reinforced polymer composites under seawater and sea-sand concrete coupled with harsh outdoor environments. Adv. Struct. Eng. 2020, 24, 1090-1109. [CrossRef]

40. Sumida, A.; Fujisaki, T.; Watanabe, K.; Kato, T. Heat resistance of continuous fiber reinforced plastic rods, FRPRCS-5: Fibrereinforced plastics for reinforced concrete structures Volume 1. In Proceedings of the Fifth International Conference on FibreReinforced Plastics for Reinforced Concrete Structures, Cambridge, UK, 16-18 July 2001; Thomas Telford Publishing: London, UK, 2001; pp. 557-565. Available online: https:/ /www.icevirtuallibrary.com/doi/abs/10.1680/frprcsv1.30299.0057 (accessed on 25 December 2021).

41. Hensher, D.A. Fiber-Reinforced-Plastic (FRP) Reinforcement for Concrete Structures: Properties and Applications; Elsevier: Amsterdam, The Netherlands, 2016.

42. Wang, Y.; Wong, P.; Kodur, V. Mechanical Properties of Fibre Reinforced Polymer Reinforcing Bars at Elevated Temperatures. In ASCE-SFPE Specialty Conference on Designing Structures for Fire; Citeseer: 2003; pp. 183-192. Available online: http: / / citeseerx.ist.psu.edu/viewdoc/download?doi=10.1.1.10.7147\&rep=rep1\&type=pdf (accessed on 25 December 2021).

43. Reid, E.R.; Bilotta, A.; Bisby, L.; Nigro, E. Mechanical Properties of Fibre Reinforced Polymer Reinforcement for Concrete at High Temperature. In Proceedings of the 8th International Conference on Structures in Fire; Tongji University Press: Shanghai, China, 2014; pp. 1227-1234. Available online: https:/ / www.research.ed.ac.uk/en/publications/mechanical-properties-of-fibre-reinforcedpolymer-reinforcement- $\mathrm{f}$ (accessed on 25 December 2021).

44. Ashrafi, H.; Bazli, M.; Oskouei, A.V.; Bazli, L. Effect of Sequential Exposure to UV Radiation and Water Vapor Condensation and Extreme Temperatures on the Mechanical Properties of GFRP Bars. J. Compos. Constr. 2018, 22, 04017047. [CrossRef] 
45. Ashrafi, H.; Bazli, M.; Najafabadi, E.P.; Oskouei, A.V. The effect of mechanical and thermal properties of FRP bars on their ten-sile performance under elevated temperatures. Constr. Build. Mater. 2017, 157, 1001-1010. [CrossRef]

46. Bazli, M.; Ashrafi, H.; Jafari, A.; Zhao, X.-L.; Gholipour, H.; Oskouei, A.V. Effect of thickness and reinforcement configuration on flexural and impact behaviour of GFRP laminates after exposure to elevated temperatures. Compos. Part B Eng. 2018, 157, 76-99. [CrossRef]

47. Saafi, M. Effect of fire on FRP reinforced concrete members. Compos. Struct. 2002, 58, 11-20. [CrossRef]

48. Adam, M.A.; Said, M.; Mahmoud, A.A.; Shanour, A.S. Analytical and experimental flexural behavior of concrete beams rein-forced with glass fiber reinforced polymers bars. Constr. Build. Mater. 2015, 84, 354-366. [CrossRef]

49. Bazli, M.; Abolfazli, M. Mechanical Properties of Fibre Reinforced Polymers under Elevated Temperatures: An Overview. Polymers 2020, 12, 2600. [CrossRef] [PubMed]

50. Bazli, M.; Zhao, X.-L.; Jafari, A.; Ashrafi, H.; Bai, Y.; Raman, R.S.; Khezrzadeh, H. Mechanical properties of pultruded GFRP pro-files under seawater sea sand concrete environment coupled with UV radiation and moisture. Constr. Build. Mater. 2020, 258, 120369. [CrossRef]

51. Bilotta, A.; Compagnone, A.; Esposito, L.; Nigro, E. Structural behaviour of FRP reinforced concrete slabs in fire. Eng. Struct. 2020, 221, 111058. [CrossRef]

52. Hajiloo, H.; Green, M.F.; Noël, M.; Bénichou, N.; Sultan, M. Fire tests on full-scale FRP reinforced concrete slabs. Compos. Struct. 2017, 179, 705-719. [CrossRef]

53. Daghash, S.M.; Ozbulut, O.E. Flexural performance evaluation of NSM basalt FRP-strengthened concrete beams using digital image correlation system. Compos. Struct. 2017, 176, 748-756. [CrossRef]

54. Bisby, L.; Chen, J.-F.; Li, S.; Stratford, T.; Cueva, N.; Crossling, K. Strengthening fire-damaged concrete by confinement with fi-bre-reinforced polymer wraps. Eng. Struct. 2011, 33, 3381-3391. [CrossRef]

55. Ahmed, A.; Kodur, V. Effect of bond degradation on fire resistance of FRP-strengthened reinforced concrete beams. Compos. Part B Eng. 2011, 42, 226-237. [CrossRef]

56. Leone, M.; Matthys, S.; Aiello, M.A. Effect of elevated service temperature on bond between FRP EBR systems and concrete. Compos. Part B Eng. 2009, 40, 85-93. [CrossRef]

57. Firmo, J.; Correia, J.; Pitta, D.; Tiago, C.; Arruda, M. Experimental characterization of the bond between externally bonded rein-forcement (EBR) CFRP strips and concrete at elevated temperatures. Cem. Concr. Compos. 2015, 60, 44-54. [CrossRef]

58. Tufail, M.; Shahzada, K.; Gencturk, B.; Wei, J. Effect of elevated temperature on mechanical properties of limestone, quartzite and granite concrete. Int. J. Concr. Struct. Mater. 2017, 11, 17-28. [CrossRef]

59. Bazli, M.; Ashrafi, H.; Oskouei, A.V. Experiments and probabilistic models of bond strength between GFRP bar and different types of concrete under aggressive environments. Constr. Build. Mater. 2017, 148, 429-443. [CrossRef]

60. Bazli, M.; Ashrafi, H.; Oskouei, A.V. Effect of harsh environments on mechanical properties of GFRP pultruded profiles. Compos. Part B Eng. 2016, 99, 203-215. [CrossRef]

61. Bazli, M.; Bazli, L.; Rahmani, R.; Mansoor, S.; Ahmadi, M.; Pouriamanesh, R. Concrete filled FRP-PVC tubular columns used in the construction sector: A review. J. Compos. Compd. 2019, 2, 155-162. [CrossRef]

62. Bazli, M.; Ashrafi, H.; Jafari, A.; Zhao, X.-L.; Raman, R.S.; Bai, Y. Effect of Fibers Configuration and Thickness on Tensile Behavior of GFRP Laminates Exposed to Harsh Environment. Polymers 2019, 11, 1401. [CrossRef] [PubMed]

63. Gooranorimi, O.; Nanni, A. GFRP reinforcement in concrete after 15 years of service. J. Compos. Constr. 2017, $21,04017024$. [CrossRef]

64. Gibson, A.; Wright, P.N.H.; Wu, Y.-S.; Mouritz, A.P.; Mathys, Z.; Gardiner, C.P. The Integrity of Polymer Composites during and after Fire. J. Compos. Mater. 2004, 38, 1283-1307. [CrossRef]

65. Mouritz, A.; Feih, S.; Kandare, E.; Mathys, Z.; Gibson, A.; Des Jardin, P.; Case, S.; Lattimer, B. Review of fire structural modelling of polymer composites. Compos. Part A Appl. Sci. Manuf. 2009, 40, 1800-1814. [CrossRef]

66. Di Ludovico, M.; Piscitelli, F.; Prota, A.; Lavorgna, M.; Mensitieri, G.; Manfredi, G. Improved mechanical properties of CFRP lam-inates at elevated temperatures and freeze-thaw cycling. Constr. Build. Mater. 2012, 31, 273-283. [CrossRef]

67. Jafari, A.; Bazli, M.; Ashrafi, H.; Oskouei, A.V.; Azhari, S.; Zhao, X.-L.; Gholipour, H. Effect of fibers configuration and thickness on tensile behavior of GFRP laminates subjected to elevated temperatures. Constr. Build. Mater. 2019, 202, 189-207. [CrossRef]

68. Gibson, A.; Torres, M.O.; Browne, T.; Feih, S.; Mouritz, A. High temperature and fire behaviour of continuous glass fibre/polypropylene laminates. Compos. Part A Appl. Sci. Manuf. 2010, 41, 1219-1231. [CrossRef]

69. Jia, D.-G.; Gao, W.-Y.; Duan, D.-X.; Yang, J.; Dai, J.-G. Full-range behavior of FRP-to-concrete bonded joints subjected to com-bined effects of loading and temperature variation. Eng. Fract. Mech. 2021, 254, 107928. [CrossRef]

70. Krzywon, R. Behavior of EBR FRP Strengthened Beams Exposed to Elevated Temperature. Procedia Eng. 2017, 193, 297-304. [CrossRef]

71. Bhatt, P.P.; Kodur, V.K.R.; Shakya, A.M.; Alkhrdaji, T. Performance of insulated FRP-strengthened concrete flexural members under fire conditions. Front. Struct. Civ. Eng. 2021, 15, 177-193. [CrossRef]

72. Shier, G.W.R.; Green, M.F. Performance of Postcured CFRP-Strengthened Reinforced Concrete Beams at Elevated Temperatures. J. Compos. Constr. 2017, 21, 04017008. [CrossRef]

73. Illam, K.J. Constitutive model for the triaxial behaviour of concrete. Proc. Intl. Assoc. Bridge Structl. Engrs 1975, 19, 1-30. 
74. Dahmani, L.; Khennane, A.; Kaci, S. Crack identification in reinforced concrete beams using ANSYS software. Strength Mater. 2010, 42, 232-240. [CrossRef]

75. Hognestad, E.; Hanson, N.W.; McHenry, D. Concrete stress distribution in ultimate strength design. J. Proc. 1955, 52, 455-480.

76. Martinelli, E.; Napoli, A.; Nunziata, B.; Realfonzo, R. RC beams strengthened with mechanically fastened composites: Experimental results and numerical modeling. Polymers 2014, 6, 613-633. [CrossRef]

77. Naser, M.; Hawileh, R.A.; Abdalla, J. Modeling Strategies of Finite Element Simulation of Reinforced Concrete Beams Strengthened with FRP: A Review. J. Compos. Sci. 2021, 5, 19. [CrossRef]

78. Bisby, L.A. Fire Behaviour of Fibre-Reinforced Polymer (FRP) Reinforced or Confined Concrete; Queen's University: Kingston, ON, Canada, 2003. Available online: https://www.researchgate.net/profile/Luke-Bisby/publication/36189430_Fire_behaviour_ of_fibre-reinforced_polymer_FRP_rein-forced_or_confined_concrete_microform/links/55cf69d808ae502646aa440e/Firebehaviour-of-fibre-reinforced-polymer-FRP-reinforced-or-confined-concrete-microform.pdf (accessed on 25 December 2021).

79. Bisby, L.A.; Williams, B.K.; Green, M.F.; Kodur, V.K. Studies on the fire behaviour of FRP reinforced and/or strengthened con-crete members. In Proceedings of the 2nd International Conference on the Durability of Fibre Reinforced Polymer Composites for Construction, Montréal, QC, Canada, 29-31 May 2002. Available online: https://www.researchgate.net/publication/44077599 _Studies_on_the_fire_behaviour_of_FRP_reinforced_andor_strengthened_concrete_members (accessed on 25 December 2021).

80. Mahesh, C.; Govindarajulu, K.; Murthy, V.B. Verification of numerical homogenization approach in predicting thermal conductivities of fiber reinforced composites with voids and randomly distributed fibers. Int. J. Comput. Mater. Sci. Eng. 2020, 9. [CrossRef]

81. Mahesh, C.; Govindarajulu, K.; Balakrishna Murthy, V. Simulation-based verification of homogenization approach in predict-ing effective thermal conductivities of wavy orthotropic fiber composite. Int. J. Comput. Mater. Sci. Eng. 2019, 8, 1950015.

82. Hawileh, R.A.; Naser, M.; Zaidan, W.; Rasheed, H. Modeling of insulated CFRP-strengthened reinforced concrete T-beam ex-posed to fire. Eng. Struct. 2009, 31, 3072-3079. [CrossRef]

83. Kodur, V.K.R.; Ahmed, A. Numerical Model for Tracing the Response of FRP-Strengthened RC Beams Exposed to Fire. J. Compos. Constr. 2010, 14, 730-742. [CrossRef]

84. Blontrock, H.; Taerwe, L.; Vandevelde, P. Fire tests on concrete beams strengthened with fibre composite laminates. In Proceedings of the International PhD Symposium in Civil Engineering, Vienna, Austria, 5-7 October 2000; 2, pp. 151-161. Available online: http:/ /hdl.handle.net/1854/LU-130382 (accessed on 25 December 2021).

85. Ahmed, A.; Kodur, V. The experimental behavior of FRP-strengthened RC beams subjected to design fire exposure. Eng. Struct. 2011, 33, 2201-2211. [CrossRef]

86. Kodur, V.K.R.; Yu, B. Evaluating the Fire Response of Concrete Beams Strengthened with Near-Surface-Mounted FRP Reinforcement. J. Compos. Constr. 2013, 17, 517-529. [CrossRef]

87. Dai, J.-G.; Gao, W.-Y.; Teng, J.G. Finite Element Modeling of Insulated FRP-Strengthened RC Beams Exposed to Fire. J. Compos. Constr. 2015, 19, 04014046. [CrossRef]

88. Firmo, J.P.; Arruda, M.R.T.; Correia, J. Numerical simulation of the fire behaviour of thermally insulated reinforced concrete beams strengthened with EBR-CFRP strips. Compos. Struct. 2015, 126, 360-370. [CrossRef]

89. Jadooe, A.; Al-Mahaidi, R.; Abdouka, K. Bond behavior between NSM CFRP strips and concrete exposed to elevated tempera-ture using cement-based and epoxy adhesives. J. Compos. Constr. 2017, 21, 04017033. [CrossRef]

90. Raoof, S.; Bournas, D.A. Bond between TRM versus FRP composites and concrete at high temperatures. Compos. Part B Eng. 2017, 127, 150-165. [CrossRef]

91. Gamage, J.; Al-Mahaidi, R.; Wong, M. Bond characteristics of CFRP plated concrete members under elevated temperatures. Compos. Struct. 2006, 75, 199-205. [CrossRef]

92. Stratford, T.; Gillie, M.; Chen, J.; Usmani, A. Bonded Fibre Reinforced Polymer Strengthening in a Real Fire. Adv. Struct. Eng. 2009, 12, 867-878. [CrossRef]

93. Dai, J.-G.; Gao, W.-Y.; Teng, J.G. Bond-Slip Model for FRP Laminates Externally Bonded to Concrete at Elevated Temperature. J. Compos. Constr. 2013, 17, 217-228. [CrossRef]

94. Dong, K.; Hu, K. Development of bond strength model for CFRP-to-concrete joints at high temperatures. Compos. Part B Eng. 2016, 95, 264-271. [CrossRef]

95. Obaidat, Y.T.; Barham, W.S.; Abdelrahman, B.N. Effect of elevated temperature on the bond behavior between near Surface Mounted-Carbon Fiber Reinforced Polymers strips and Recycled Aggregate concrete. Constr. Build. Mater. 2020, 251, 118970. [CrossRef]

96. Bazli, M.; Zhao, X.-L.; Bai, Y.; Raman, R.S.; Al-Saadi, S. Bond-slip behaviour between FRP tubes and seawater sea sand concrete. Eng. Struct. 2019, 197. [CrossRef]

97. McIntyre, E.R.; Bisby, L.; Stratford, T. Bond strength of FRP reinforcement in concrete at elevated temperature. In Proceedings of the 7th international Conference on Fiber Reinforced Polymer (FRP) Composites in Civil Engineering (CICE 2014), Vancouver, BC, Canada, 20-22 August 2014. Available online: https://www.semanticscholar.org/paper/BOND-STRENGTH-OFFRP-REINFORCEMENT-IN-CONCRETE-AT-McIntyre-Bisby/74a3a4510985599259a235694d19e1ba1f195c24 (accessed on 25 December 2021). 
98. Sólyom, S.; Balázs, G.L.; Di Benedetti, M.; Guadagnini, M.; Zappa, E. Bond Strength of GFRP Rebars In Concrete at Elevated Temperature. Adv. Compos. Constr. ACIC 2017, 337-343. Available online: https:/ / www.researchgate.net/publication/33367084 1_Bond_Strength_of_GFRP_Rebars_In_Concrete_at_Elevated_Temperature (accessed on 25 December 2021).

99. Rosa, I.; Firmo, J.; Correia, J.; Barros, J. Bond behaviour of sand coated GFRP bars to concrete at elevated temperature-Definition of bond vs. slip relations. Compos. Part B Eng. 2019, 160, 329-340. [CrossRef]

100. Davalos, J.F.; Chen, Y.; Ray, I. Effect of FRP bar degradation on interface bond with high strength concrete. Cem. Concr. Compos. 2008, 30, 722-730. [CrossRef]

101. Adelzadeh, M.; Hajiloo, H.; Green, M.F. Numerical Study of FRP Reinforced Concrete Slabs at Elevated Temperature. Polymers 2014, 6, 408-422. [CrossRef]

102. Lin, X.; Zhang, Y. Nonlinear finite element analyses of steel/FRP-reinforced concrete beams in fire conditions. Compos. Struct. 2013, 97, 277-285. [CrossRef]

103. Rafi, M.M.; Nadjai, A.; Ali, F. Finite element modeling of carbon fiber-reinforced polymer reinforced concrete beams under elevated temperatures. ACI Struct. J. 2008, 105, 701.

104. Jamalan, M.H.; Fu, F. Numerical Analysis on Bond Strength of FRP Re-bars under Elevated Temperature. IOP Conf. Ser. Mater. Sci. Eng. 2018, 371, 012013. [CrossRef]

105. Yu, B.; Kodur, V. Factors governing the fire response of concrete beams reinforced with FRP rebars. Compos. Struct. 2013, 100, 257-269. [CrossRef]

106. Rafi, M.M.; Nadjai, A. Experimental behaviour of carbon FRP reinforced concrete beams at ambient and elevated tempera-tures. J. Adv. Concr. Technol. 2008, 6, 431-441. [CrossRef]

107. Rafi, M.M.; Nadjai, A.; Ali, F. Fire resistance of carbon FRP reinforced-concrete beams. Mag. Concr. Res. 2007, 59, 245-255. [CrossRef]

108. Rafi, M.M.; Nadjai, A.; Ali, F.; O'Hare, P. Evaluation of Thermal Resistance of FRP Reinforced Concrete Beams in Fire. J. Struct. Fire Eng. 2011, 2, 91-107. [CrossRef]

109. Albu-Hassan, N.H.; Al-Thairy, H. Experimental and numerical investigation on the behavior of hybrid concrete beams rein-forced with GFRP bars after exposure to elevated temperature. In Structures; Elsevier: Amsterdam, The Netherlands, 2020 ; pp. 537-551.

110. Zhao, J.; Li, G.; Wang, Z.; Zhao, X.-L. Fatigue behavior of concrete beams reinforced with glass- and carbon-fiber reinforced polymer (GFRP/CFRP) bars after exposure to elevated temperatures. Compos. Struct. 2019, 229, 111427. [CrossRef]

111. Faruqi, M.; Roy, S.; Salem, A. Elevated temperature deflection behavior of concrete members reinforced with FRP bars. J. Fire Prot. Eng. 2012, 22, 183-196. [CrossRef]

112. Dotreppe, J.-C.; Franssen, J.-M. The use of numerical models for the fire analysis of reinforced concrete and composite struc-tures. Eng. Anal. 1985, 2, 67-74. [CrossRef]

113. Solyom, S.; Di Benedetti, M.; Guadagnini, M.; Balázs, G.L. Effect of temperature on the bond behaviour of GFRP bars in concrete. Compos. Part B Eng. 2020, 183, 107602. [CrossRef]

114. Rosa, I.C.; Firmo, J.P.; Correia, J.R.; Mazzuca, P. Influence of elevated temperatures on the bond behaviour of ribbed Gfrp bars in concrete. Cem. Concr. Compos. 2021, 122, 104119. [CrossRef]

115. Prokeš, J.; Rozsypalová, I.; Girgle, F.; Daněk, P.; Štěpánek, P. Effects of elevated temperature on the behaviour of concrete beams reinforced with fiber reinforced polymers. IOP Conf. Ser. Mater. Sci. Eng. 2021, 1039, 012008. [CrossRef]

116. Protchenko, K.; Szmigiera, E. Post-Fire Characteristics of Concrete Beams Reinforced with Hybrid FRP Bars. Materials 2020, 13, 1248. [CrossRef] [PubMed]

117. Soudki, K.; Alkhrdaji, T. Guide for the Design and Construction of Externally Bonded FRP Systems for Strengthening Concrete Structures (ACI 440.2R-02). 2005. Available online: https:/ / ascelibrary.org/doi/10.1061/40753\%28171\%29159 (accessed on 25 December 2021). [CrossRef]

118. CSA. CSA-S806-02, Design and Construction of Building Components with Fibre-Reinforced Polymers; CSA: Toronto, ON, Canada, 2002. Available online: https:/ / repository.ust.hk/ir/Record/1783.1-40537 (accessed on 25 December 2021).

119. Shahawy, M.; Mirmiran, A.; Beitelman, T. Tests and modeling of carbon-wrapped concrete columns. Compos. Part B Engineering 2000, 31, 471-480. [CrossRef]

120. Xiao, Y.; Wu, H. Compressive Behavior of Concrete Confined by Carbon Fiber Composite Jackets. J. Mater. Civ. Eng. 2000, 12, 139-146. [CrossRef]

121. Al-Salloum, Y.; Elsanadedy, H.M.; Abadel, A.A. Behavior of FRP-confined concrete after high temperature exposure. Constr. Build. Mater. 2011, 25, 838-850. [CrossRef]

122. Cerniauskas, G.; Tetta, Z.; Bournas, D.A.; Bisby, L.A. Concrete confinement with TRM versus FRP jackets at elevated temperatures. Mater. Struct. 2020, 53, 1-14. [CrossRef]

123. Spoelstra, M.R.; Monti, G. FRP-confined concrete model. J. Compos. Constr. 1999, 3, 143-150. [CrossRef]

124. Bisby, L.A.; Kodur, V.K.R.; Green, M. Fire Endurance of Fiber-Reinforced Polymer-Confined Concrete Columns. ACI Struct. J. 2005, 102, 883-891. [CrossRef]

125. Chowdhury, E.U.; Bisby, L.A.; Green, M.; Kodur, V.K. Investigation of insulated FRP-wrapped reinforced concrete columns in fire. Fire Saf. J. 2007, 42, 452-460. [CrossRef]

126. Chowdhury, E.; Bisby, L.; Green, M.; Bénichou, N.; Kodur, V. Heat transfer and structural response modelling of FRP confined rectangular concrete columns in fire. Constr. Build. Mater. 2012, 32, 77-89. [CrossRef] 
127. El-Gamal, S.; Al-Jabri, K.; Al-Mahri, A.; Al-Mahrouqi, S. Effects of Elevated Temperatures on the Compressive Strength Capacity of Concrete Cylinders Confined with FRP Sheets: An Experimental Investigation. Int. J. Polym. Sci. 2015, 2015, 1-10. [CrossRef]

128. Song, J.; Gao, W.-Y.; Ouyang, L.-J.; Zeng, J.-J.; Yang, J.; Liu, W.-D. Compressive behavior of heat-damaged square concrete prisms confined with basalt fiber-reinforced polymer jackets. Eng. Struct. 2021, 242, 112504. [CrossRef]

129. Al-Salloum, Y.A.; Almusallam, T.H.; Elsanadedy, H.M.; Iqbal, R.A. Effect of elevated temperature environments on the resid-ual axial capacity of RC columns strengthened with different techniques. Constr. Build. Mater. 2016, 115, 345-361. [CrossRef]

130. Hisham, M.; Hamdy, G.A.; El-Mahdy, O.O. Prediction of temperature variation in FRP-wrapped RC columns exposed to fire using artificial neural networks. Eng. Struct. 2021, 238, 112219. [CrossRef]

131. Cree, D.; Chowdhury, E.; Green, M.; Bisby, L.; Bénichou, N. Performance in fire of FRP-strengthened and insulated reinforced concrete columns. Fire Saf. J. 2012, 54, 86-95. [CrossRef]

132. Kodur, V.K.; Bisby, L.A.; Green, M.F. Experimental evaluation of the fire behaviour of insulated fibre-reinforced-polymerstrengthened reinforced concrete columns. Fire Saf. J. 2006, 41, 547-557. [CrossRef]

133. Luck, J.D.; Bazli, M.; Rajabipour, A. Bond between Fibre-Reinforced Polymer Tubes and Sea Water Sea Sand Concrete: Mechanisms and Effective Parameters: Critical Overview and Discussion. Fibers 2022, 10, 8. [CrossRef]

134. Bazli, M.; Li, Y.-L.; Zhao, X.-L.; Raman, R.S.; Bai, Y.; Al-Saadi, S.; Haque, A. Durability of seawater and sea sand concrete filled filament wound FRP tubes under seawater environments. Compos. Part B Eng. 2020, 202, 108409. [CrossRef]

135. Bazli, M.; Zhao, X.-L.; Bai, Y.; Raman, R.S.; Al-Saadi, S.; Haque, A. Durability of pultruded GFRP tubes subjected to seawater sea sand concrete and seawater environments. Constr. Build. Mater. 2020, 245, 118399. [CrossRef]

136. Bazli, M.; Zhao, X.-L.; Raman, R.S.; Bai, Y.; Al-Saadi, S. Bond strength durability between FRP tubes and seawater sea sand concrete under sea water condition. In Proceedings of the Asia-Pacific Conference on FRP in Structures, 2019. Available online: https:/ / research.monash.edu/en/publications/bond-strength-durability-between-frp-tubes-and-seawater-sea-sand- (accessed on 25 December 2021).

137. Guo, Z.; Xia, L.; Lin, Q.; Chen, Y. Test on mechanical behavior of pultruded concrete-filled GFRP tubular short columns after elevated temperatures. Compos. Struct. 2020, 257, 113163. [CrossRef]

138. Tabatabaeian, M.; Khaloo, A.; Azizmohammadi, M. The effects of elevated temperatures on the performance of concrete-filled pultruded GFRP tubular columns. Thin Walled Struct. 2021, 169, 108404. [CrossRef] 